\title{
Scientific basis for the industrialization of traditionally used plants of the Rosaceae family
}

\author{
P. Garcia-Oliveira ${ }^{\mathrm{a}}$, M. Fraga-Corral ${ }^{\mathrm{a}, \mathrm{b}}$, A.G. Pereira ${ }^{\mathrm{a}, \mathrm{b}}$, C. Lourenço-Lopes ${ }^{\mathrm{a}}$, C. Jimenez-Lopez $^{\mathrm{a}, \mathrm{b}}$, \\ M.A. Prieto ${ }^{\mathrm{a}, *}$, J. Simal-Gandara ${ }^{\mathrm{a}, *}$ \\ ${ }^{\mathrm{a}}$ Nutrition and Bromatology Group, Analytical and Food Chemistry Department, Faculty of Food Science and Technology, University of Vigo, Ourense Campus, E-32004 \\ Ourense, Spain \\ ${ }^{\mathrm{b}}$ Centro de Investigação de Montanha (CIMO), Instituto Politécnico de Bragança, Campus de Santa Apolonia, 5300-253 Bragança, Portugal
}

\section{A R T I C L E I N F O}

\section{Keywords:}

Traditionally used plants

Ethnobotanic

Rosaceae family

Bioactive compounds

\begin{abstract}
A B S T R A C T
Plants have been traditionally used for the treatment of different types of illness, due to biomolecules with recognised benefits. Rosaceae family is used in traditional Galician medicine. The following plants Agrimonia eupatoria, Crataegus monogyna, Filipendula ulmaria, Geum urbanum, Potentilla erecta and Rosa canina are usually found in treatments. The aim of this study is to perform an ethnobotanical review about the bioactive compounds of these plants and their different bioactivities, both studied in vitro and in vivo. The nature of the bioactive compounds is varied, highlighting the presence of different phenolic compounds, such as phenolic acids, flavonoids or tannins. Understanding the beneficial effects of the administration of the whole plant or target tissues from A. eupatoria, C. monogyna, F. ulmaria, G. urbanum, P. erecta and $R$. canina as well as those from their individual compounds could lead to the development of new drugs based on the use of natural ingredients.
\end{abstract}

\section{Oral tradition and the knowledge based on trial and error}

\subsection{History of traditionally used Plants: Worldwide to Galicia (NW Spain)}

Since the ancient times, people instinctively sought the remedies for pain and diverse illness in the surrounding nature (Sengupta, Gaurav, \& Tiwari, 2018; Srivastava, 2018). All knowledge was based on experience, as there was no information about the reasons for the disease or which plant and its form of consumption could be useful for its treatment. After thousands of years of trial and error throughout human history, specific plants consumed via oral administration were identified for the treatment of specific diseases, therefore known as medicinal plants (Srivastava, 2018). Plants may contain diverse chemical compounds, named active or bioactive compounds, such as alkaloids or essential oils (EO) (Pérez, 1998). The correct administration of these biomolecules may have beneficial effects on health. In fact, some of these bioactive compounds are the foundation of modern medicine drugs and they represent an alternative source of innovative ingredients with further applications in food and cosmetic industries. Along the history of the traditionally used plants, at first, information was passed orally from generation to generation, until the start of writing. Numerous texts describe the use of different plants in ancient civilizations, such as the Sumerian, Egyptian, Indian, Chinese, Greek, Roman or Arab (Sengupta et al., 2018; Srivastava, 2018). The Ebers Papyrus contains descriptions of different treatments, based on plants, to treat skin, urinary, ophthalmologic and other infections (Lennihan, 2014; Srivastava, 2018). Some of the treatments from the Ayurveda Indian medical system and Traditional Chinese medicine have similar basis and the species they described are still used today (Lennihan, 2014; Srivastava, 2018). Initially, plants were consumed raw, and later, people added them to hot water (W) to create soup and tea. As knowledge grew, different herbs were combined to elaborate more complex treatises (Lennihan, 2014). Ancient Greeks are considered the parents of modern medicine, as they combined traditional practices with scientific thinking. Hippocrates, Galen and Dioscorides, among other authors, showed their interest in the deeper application of plants by writing vast treatises (Srivastava, 2018). In Corpus Hippocraticum, different herbal medicines and their forms of treatment were described for each disease (Lennihan, 2014; Pahlow, 1994). Galen differentiated between the use of plants "at natural" (meaning in powder form) and the galenic preparations: bioactive compounds were concentrated in $\mathrm{W}$, ethanol (Et) or vinegar, then used in ointment, plasters or other galenic forms (Pahlow, 1994). Dioscorides wrote De Materia Medica, with descriptions, modes of collection, preparation and therapeutic effects of

\footnotetext{
* Corresponding authors.

E-mail addresses: mprieto@uvigo.es (M.A. Prieto), jsimal@uvigo.es (J. Simal-Gandara).
} 


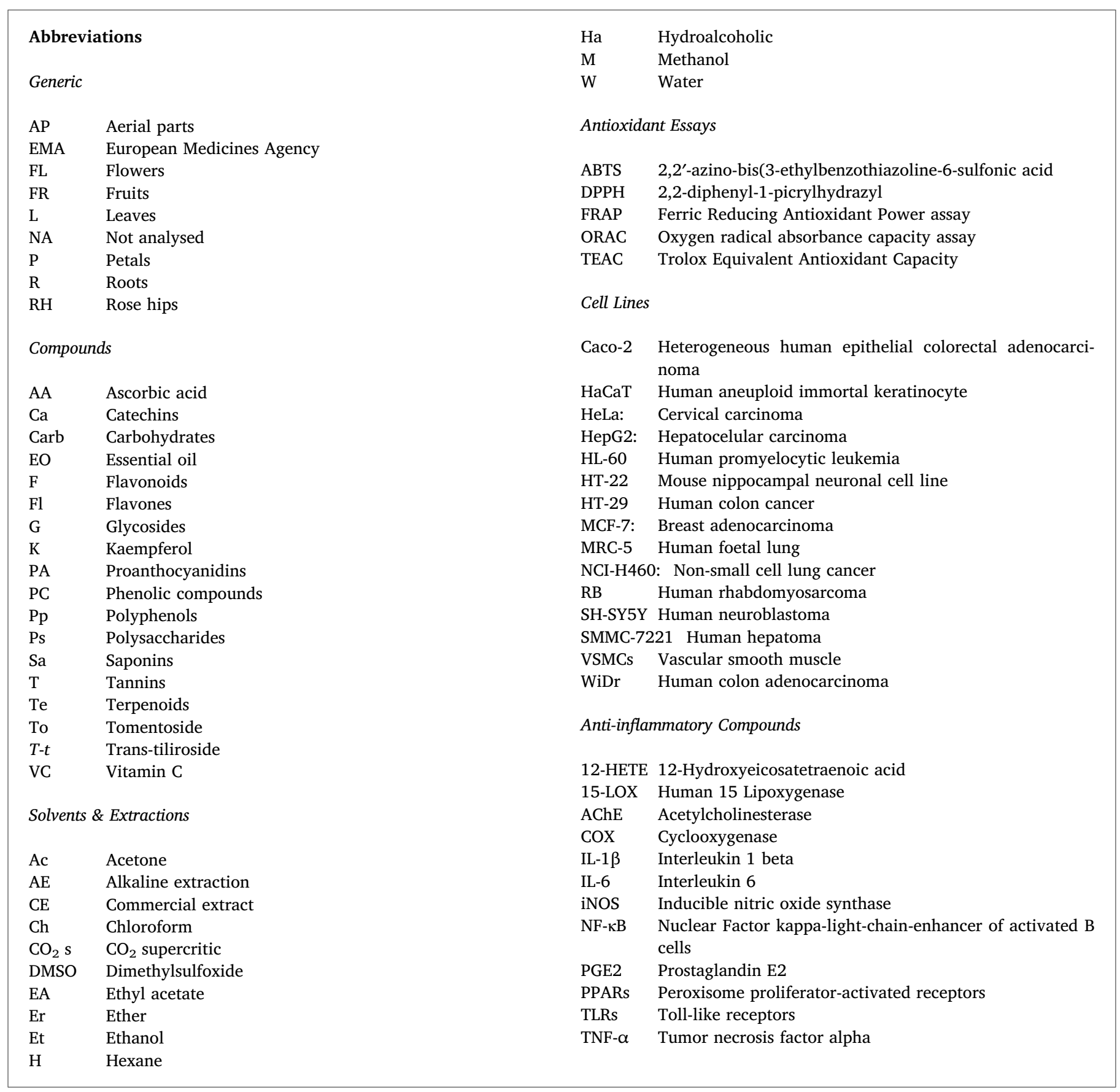

more than 600 MP (Srivastava, 2018). The Greek knowledge was extended by the Romans and Arabians. A scientific regression was suffered during the Middle Ages, as science and magic were mixed. Owing to their knowledge of Latin and Greek, clerics conserved the ancient knowledge (Pahlow, 1994). Until the 16th century, with the advent of iatochemistry (chemical medicine), plants have been the major source of treatments and relief to some of the most diverse diseases, such as digestive problems, microbial infections, cancer and even neurodegenerative illness (Sengupta et al., 2018; Srivastava, 2018). Synthetic drugs were available for people with more economic resources, while remedies based on plants remained the option to treat poor people (Lennihan, 2014; Srivastava, 2018). In the 18th century, urban citizens preferred pharmaceutical drugs rather than traditional medicine. However, drug side effects became known and medicinal plans resurfaced rapidly (Lennihan, 2014). In early 19th century, the development of chemical methods allowed the discovery and isolation of alkaloids (such as morphine from Papaver somniferum or quinine from Cinchona officinalis), tannins (T), vitamins, hormones, sapponins (Sa), among other bioactive compounds from vegetal origin starting scientific pharmacy (Srivastava, 2018).

Regarding traditional Spanish medicine, it has the heritage of hundreds of years of different people that influenced the country: diverse Iberian people, Greeks, Romans, Arabs and Orientals as well as German traditions (Verde, Rivera, Fajardo, Obón, \& Cebrián, 2008). Some Roman authors described the traditional use of plants by Iberian tribes (de Santayana, Morales, Tardío, Aceituno, \& Molina, 2014). During Middle Ages, Ibn al-Baytar,an Andalusian doctor and botanist) wrote the Tratado de simples, where he described more than 1400 species with beneficial properties (de Santayana et al., 2014). However, as the Christian religion increased its influence, the human body was considered a finite recipient for a soul, which aspired to divine salvation. In these ages, people were suspicious of medicine, and healers 
were often considered heretics (Verde et al., 2008). Until the early 19th century, the Spanish Inquisition pursued and convicted many healers, men and women, of heresy (Verde et al., 2008). Little by little, science overcome religion, and two differentiated figures appeared: the physician, who carried out the diagnosis, and the pharmacist, who prepared the drugs (Mosquera Paans, 2013). After the Spanish Flu pandemic of 1918, which caused a dramatic number of deaths, traditional medicine started to grow, particularly among the population with less economic resources to obtain chemical drugs (Mosquera Paans, 2013). The botanist Pio Font Quer wrote Plantas medicinales. El Dioscórides renovado, which is the most complete text about application of Iberian plants and is still a basic reference (de Santayana et al., 2014). It includes botanic, chemical and pharmacologic data, names and local uses. He is considered one of the fathers of ethnobotany in Spain (de Santayana et al., 2014). The roots of traditional medicine lead to a new golden age of natural ingredients obtained from plants, whose use is gradually legislated more exhaustively and scientific research is favoured (Mosquera Paans, 2013).

Galicia is a region located in the NW of Spain. Not long ago, in case of ailment, the people had to seek the experience of the elders, especially in the rural areas (Rodríguez González, 2008). In these zones, visiting a doctor or buying a drug was a luxury. Healers ("menciñeiros" in Galician) practiced "shamanism" and the Christian religion, integrating magic and religion. These healers used their knowledge of MP combined with spells, magic symbolism and also Christian traditions (Mosquera Paans, 2013; Rodríguez González, 2008). Actually, they were important members of the society in the rural areas, since the medical advances took a long time to arrive. Regarding the important figures, the conservation of Galician traditional medicine, Father Sarmiento (18th century) stands out. He understood the necessity to understand, recover and preserve Galician tradition and popular culture (Mosquera Paans, 2013).

As in other regions, Galician traditional medicine has almost been replaced by modern medicine. However, some people have learned and continue transmitting this ancient knowledge, thereby conserving it (González-Hernández, Romero, Rodríguez-Guitián, \& Rigueiro, 2004). As popular wisdom is concentrated on in the elder population and in the rural areas, thousands of years of experience are at risk of disappearing when these people pass away. Preserving the ancient knowledge is exceedingly important, as the study of the traditional use of certain plant species could lead to the re-discovery of active compounds (initially found by our ancestors) with different applications, including medicine, nutrition, cosmetics, etc. (Franco, Guitián, \& Resúa, 2013).

\subsection{Current uses of natural ingredients extracted from plants}

\subsubsection{Food}

Nowadays, the consumption of vegetal-based nutrients has been prompted by different reasons. In most of the developed countries where nutrition does not represent an issue for most of the population, consumers' demands are focused on the improvement of the quality of the food. Some of these demands include the replacement of synthetic or artificial ingredients, additives or colorants for natural ones which are not considered to have side-effects. Other demand is to increase the presence of organic and fresh products in the market, as well as, the increment of vegetal-based products which may be included in alternative diets such as vegan or vegetarian ones. However, another important concern is about people with low economic inputs whose nutrition levels are scarce which may induce to the ingestion of unsafe products and thus cause diseases that might become chronic and even fatal. The use of vegetal-based diets has been demonstrated to be an economical approach to feed people. In this sense, since the 50 's the rise on the global population has represented a challenge due to the parallel increment of animal protein intake. Plants have been described to represent an alternative source of protein which may help to balance or even reduce the animal protein production (Asioli et al., 2017; Day, 2013; Flood, 2010). Traditionally many plants have been cultivated since ancient times, due to their nutritional and beneficial properties. Nowadays, it is very common to include some of them in our diet, as it is the case of different spices, such as thyme, rosemary, parsley, coriander; vegetables like tomatoes, garlic, pumpkins, onions, or leeks; and different fruit trees for example (López et al., 2018; Pahlow, 1994; Pinela et al., 2016; Vieira et al., 2017). Plants can be eaten raw, as in salads, cooked or in infusions and can be used in different ways: to

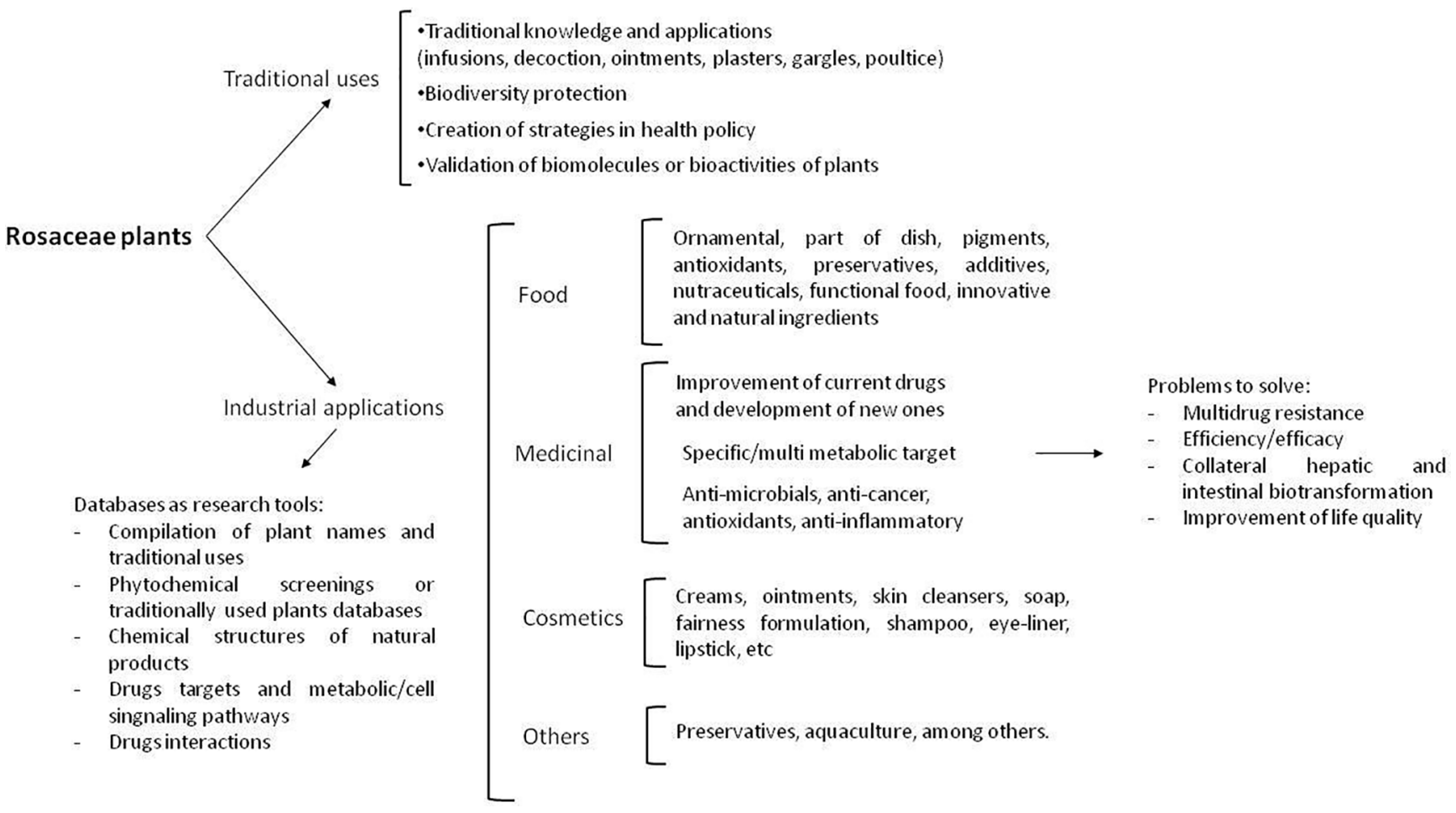

Fig. 1. Different traditional and industrial uses of Rosaceae plants. 
garnish, like food ingredients, aromatize, or they can be consumed for their beneficial properties. Some herbal products are sold in pharmacies as dietary supplements, teas, capsules, extracts or powders used in selfmedication to prevent diseases, soothe pains, relax, improve wellbeing, etc. Several studies have proven the efficacy of these products in health (Martín Ortega \& Segura Campos, 2019; Srivastava, 2018).

Whole plants and some of their compounds could be included in foods or beverages, obtaining a "nutraceutical" food (also called nutraceutic), which, in addition to nutritional function, has different health benefits, helping in the prevention and treatment of diseases (Gulati, Ottaway, Jennings, Coppens, \& Gulati, 2019; Lubbe \& Verpoorte, 2011). In fact, this tendency to implement the properties of the products and the wide use of functional foods has commenced to blur the limits between pharma and nutrition (Corbo, Bevilacqua, Petruzzi, Casanova, \& Sinigaglia, 2014). Currently, different nutraceuticals are available for consumers. One of the most well-known examples are dairy products (e.g. milk, yogurts and margarines) enriched with phytosterols, which have been proven to reduce the intestinal absorption of cholesterol (Tolve et al., 2019). Another example is folic acid, extracted from leafy green vegetables and legumes, commonly used to fortify cereal and their derivatives. This vitamin is considered to help in the prevention of central nervous system diseases (Samaniego-Vaesken, Alonso-Aperte, \& Varela-Moreiras, 2016). In addition to compounds, there are also examples of products supplemented with the plant itself. For example, different plant materials are used to fortify flour, including Chenopodium quinoa, Avena sativa or Hordeum vulgare, due to the high quantity of bioactive compounds of these species (Cardoso, Fernandes, Gonzaléz-Paramás, Barros, \& Ferreira, 2019).

The toxicological and carcinogenic effects associated with synthetic ingredients have triggered the replacement with natural ones and therefore food industries and academia have prompted their deeper study. Along the last decades many applications have been developed based on the use of natural biocompounds, such as the antioxidants that are present under different chemical structures. Carotenoids, anthocyanins and betalains extracted from plants have been proven to be effective natural additives for foods with antioxidants and have less toxic effects than synthetic ones (Roriz, Barros, Prieto, Morales, \& Ferreira, 2017).

The previous food applications of different species of plants are summarized in Fig. 1 and in Table 1.

\subsection{Pharmacological}

Pharmacological applications are the most known application of these raw materials (Pérez, 1998). Nowadays, the synthetic drugs of modern medicine have almost completely replaced the use of natural plants in developed nations and they are used mostly in traditional medicine in Third world and developing countries. In developed countries, traditional medicine is categorized as "alternative medicine" and is used not for the treatment of serious diseases, but for minor disorders (Martín Ortega \& Segura Campos, 2019; Srivastava, 2018).

Natural ingredients obtained from plants can be described as being applied in different ways such as being used as direct agents or as raw materials in the manufacture of drugs. Some examples of these drugs are aspirin, which derives from willow; opium-derived morphine, obtained from poppies; or the anti-tumour drug Taxol, which derives from the Pacific yew (Lennihan, 2014; Martín Ortega \& Segura Campos, 2019). In fact, it is estimated that $25-28 \%$ of drugs used in modern medicine are derived from MP, directly or indirectly (Lubbe \& Verpoorte, 2011; Martín Ortega \& Segura Campos, 2019). Regarding pharmacological applications, diverse compounds have been proved to be related to the health benefits of biomolecules extracted from plants. Some examples are described below and summarized in Fig. 1 and in Table 1.

Plants from the Asteraceae, Rutaceae, Fabaceae, Lamiaceae, Zygophyllaceae, Rhamnaceae, Liliaceae and Zingiberaceae families are

\section{范}

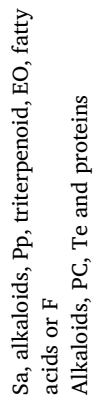
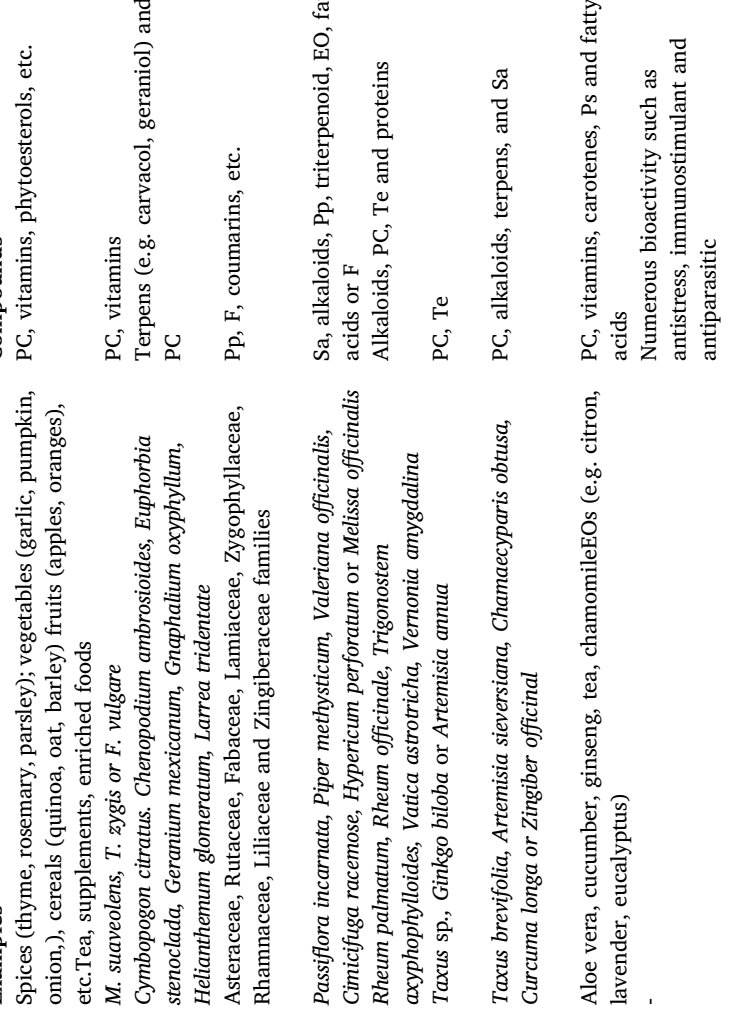

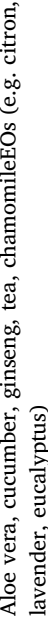
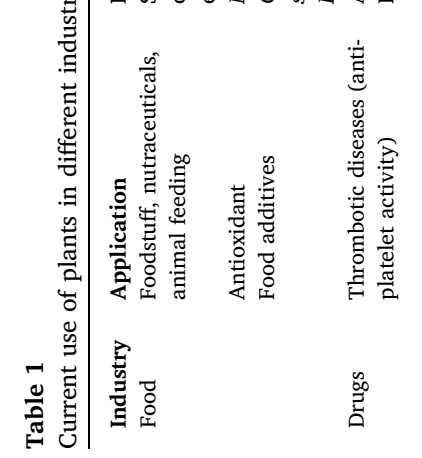
well known for their antiplatelet activity. Several bioactive compounds of these plants, specially polyphenols (Pp), flavonoids (F) and coumarins, has been proved to inhibit the ADP pathway, suppress $\mathrm{TXA}_{2}$ formation and reduce intracellular $\mathrm{Ca}^{2+}$ mobilization, among other activities (El Haouari \& Rosado, 2016).

MP are also a great source of bioactivity compounds to treat anxiety and depression. In this case, compounds such as Sa, alkaloids, Pp, F, triterpenoids, EO, and fatty acids are involved. Passiflora incarnata, Piper methysticum, Valeriana officinalis, Cimicifuga racemose, Hypericum perforatum or Melissa officinalis are examples of plants used to treat these disorders (Martins \& Brijesh, 2018). After the administration of most of the plants considered to possess medicinal properties, the antidepressant activity is related to the increase of monoamines (serotonin, dopamine or norepinephrine) levels in the brain, inhibiting their receptor systems and transporters and also reducing the activity of monoamine oxidase enzymes, which break the monoamines (Martins \& Brijesh, 2018).

Nowadays, several adverse effects of the current medication against HIV have been described. To reduce these side effects, scientists are searching for safer and more effective compounds. Several plants have shown promising anti-HIV activity (both in vitro and in vivo), such as Rheum palmatum, R. officinale, Trigonostem axyphophylloides, Vatica astrotricha, Vernonia amygdalina, Hypoxias pelargonium, Sidoides hemerocallidea and Sutherlandia frutescens. The mechanism of action of most of them has not been fully disclosed, but different compounds (alkaloids, phenolic compounds (PC), terpenoids (Te) and proteins) have been proven to interrupt the life cycle of HIV and enhance the immune system (Laila et al., 2019). Other species, for instance Sambucus nigra, Caesalpinia pulcherrima and Hypericum connatum, are also useful against other viruses like the herpes simplex virus, influenza, hepatitis, and coxsackie virus (Akram et al., 2018).

Antimicrobials may be obtained from plant matrixes, being alkaloids, PC and Te the responsible compounds of the activity. Generally, these compounds act through the disruption of the cell membrane and inhibition of different metabolic processes, such as the biosynthesis of nucleic acids or proteins. Species of genus Taxus, Ginkgo biloba or Artemisia annua have shown antimicrobial properties. A. annua also contains the anti-malaria compound artemisinin (Pandey \& Agnihotri, 2015).

Several compounds are currently used in the formulation of drugs to treat cancer, including Te, alkaloids, Sa, glycosides (G), and PC. Briefly, these compounds act through the induction of apoptosis, autophagy or cell cycle arrest of cancer cells and also through the modification of signalling pathways (Benarba \& Pandiella, 2018; Oyenihi \& Smith, 2019). To give some examples, T. brevifolia, Artemisia sieversiana, Chamaecyparis obtusa, Curcuma longa or Zingiber officinale are MP with antiproliferative effects in vitro and in vivo models (Benarba \& Pandiella, 2018; Martín Ortega \& Segura Campos, 2019; Oyenihi \& Smith, 2019).

Numerous studies have demonstrated that thousands of plants contain potent antioxidant compounds, especially PC and vitamins, due to their redox properties, the ability to chelate metals and quench singlet oxygen reactive species (Borneo, León, Aguirre, Ribotta, \& Cantero, 2009; Jaberian, Piri, \& Nazari, 2013; Ortega-Ramirez et al., 2014; Roleira et al., 2015). Their efficiency has been assessed through in vitro assays and also with in vivo supplementation studies in animal and human models (Oyenihi \& Smith, 2019). Mentha suaveolens, Thymus zygis or Foeniculum vulgare are just a few examples of plants with antioxidant properties (Stanković, Radić, Blanco-Salas, Vázquez-Pardo, \& Ruiz-Téllez, 2017). These compounds may be used to treat several diseases, such as diabetes, cancer, ageing and other health problems (Oyenihi \& Smith, 2019).

\subsubsection{Cosmetics}

Throughout the centuries, plants have been used in the treatment of different beauty problems and disorders, such as dry skin, inflammation, eczema, psoriasis, hair loss and others. Nowadays, numerous cosmetic products contain extracts or plants-derived compounds in their formulation, such as sunscreens, moisturizers, skin cleansers, body lotions, lipsticks, etc. (Aburjai \& Natsheh, 2003; Ganesan \& Choi, 2016). Regarding skin products, aloe vera and cucumber are widely used, due to their anti-inflammatory, cooling and healing properties. Other examples of plants used in cosmetics are the gingseng (anti-aging properties), tea (several bioactivities, including antioxidant, photoprotective and anti-inflammatory effects), chamomile (anti-inflammatory activity) or onion (antiallergic anti-inflammatory and antimicrobial effects) (Aburjai \& Natsheh, 2003). In hair care, plants such as Ginko biloba, aloe vera, sage and rosemary have been used, especially to promote hair growth (Aburjai \& Natsheh, 2003). EOs are also an important cosmetic product, due to their beneficial effects for skin and hair care and relaxing properties. For instance, chamomile, lavender, eucalyptus and citron EOs are appreciated in cosmetic applications for their antioxidant and anti-inflammatory properties, among others (Lubbe \& Verpoorte, 2011).

In many cases, bioactive compounds are included in the formulation of cosmetics, such as PC (e.g. quercetin, gallic acid, luteolin or catechins (Ca)), vitamins, carotenes, polysaccharides (Ps) and fatty acids. Several beneficial activities of these compounds have been described, including anti-ageing, antioxidant, anti-inflammatory and anti-microbiological (Ganesan \& Choi, 2016). The previous food applications of different species of plants are summarized in Fig. 1 and in Table 1

\subsubsection{Others}

Currently, many consumers have a bad opinion of synthetic additives used to preserve foods. Thus, the food industry is searching new natural compounds to prevent the spoilage of food produced by pathogenic microorganisms and also the oxidation of lipids. Terpens (e.g. geraniol, citral or carvacrol) and PC extracted from plants have been demonstrated to be effective as food additives due to their antimicrobial and antioxidant properties. Some plant compounds have been tested as food additives, such as the terpenes of Cymbopogon citratus and Chenopodium ambrosioides and the PC of Euphorbia stenoclada, Helianthemum glomeratumrich and Gnaphalium oxyphyllumrich (OrtegaRamirez et al., 2014).

The use of plants has been also considered a promising tool for aquaculture. Microbial diseases cause high economic losses, while the inappropriate use of antibiotics could lead to negative side effects appearing in the organisms and also in the environment. Several plats have been demonstrated to exert beneficial effects on the aquatic organism and also reduction of the pathogens present in the $\mathrm{W}$ (Van Hai, 2015). Therefore, plants are a cheaper and more sustainable treatment, since they have numerous interesting bioactivity such us promoting anti-stress and being immune-stimulants and anti-parasitic (bacterial, fungus, virus and ectoparasites) (Reverter, Tapissier-Bontemps, Sasal, \& Saulnier, 2017).

\section{Properties of traditionally used plants from Rosaceae family}

As mentioned before, the information related to traditional uses of plants is in serious danger. To record this ancient knowledge, several ethnobotanical and ethnopharmaceutical studies have been performed in different Iberian Peninsula regions, including Galicia (Franco et al., 2013; González-Hernández et al., 2004). Most of these studies are focused on the different uses of plants and their forms of consumption/ application but no extensive information about the active compounds responsible of the medicinal action has been collected. Investigating the phytochemistry is necessary to understand the relationship between their traditional uses (the result of hundreds of years of trial and error) and their bioactive compounds. In addition, this study allows the exploration of possible future uses of these plants.

In ethnobothanical studies, Rosacea family is found among the most frequently used plant families (Franco et al., 2013). In the present study, Agrimonia eupatoria, Crataegus monogyna, Filipendula ulmaria, 
Geum urbanum, Potentilla erecta and Rosa canina were chosen to perform an ethnobotanical review, because they are among the most utilised plants of this genus, and scientific studies have been carried out on their active compounds and bioactivities. All the six species mentioned can be found in the northwestern part of the Iberian Peninsula. However, the distribution of $F$. ulmaria, G. urbanum, and P. erecta have a lower density in the northwest, even though they constitute a representative flora from the northern part of the Peninsula (Castroviejo, 1986; Ministerio De Agricultura Alimentación y Medio Ambiente, 2019). Additionally, all the species can be found in all four Galician provinces: Lugo, Ourense, A Coruña and Pontevedra (Romero, 2008). The traditional uses of the selected plants (parts used, mode of application and infections treated) are described in the following paragraphs and summarized in Table 2.

\subsection{Agrimonia eupatoria}

\subsubsection{Traditional importance}

A. eupatoria is an indigenous plant from the middle and northern areas of Europe and also the temperate regions from Asia and North America (Al-snafi, 2015). Its aerial parts (AP) are usually collected during the flowering period, spring and summer, to be applied in different ways. Traditional uses reported along the Iberian Peninsula comprised diverse application modes, such as, infusion, decoction, dry extraction, wet extraction (using aqueous, oil or alcoholic solvents) and tincture (de Santayana et al., 2014; Escudero, 1999; Febrer, Blanquer, \& Pí, 2001; Romero Martín, 1998; Verde, 2008). A. eupatoria has several medicinal properties: it is an astringent, hypotensive, anti-inflammatory, antiemetic, analgesic and healing. It has been used as mouthwash, to gargle and for larynges infections, to clean varicose ulcersin renal or hepatic infections and to control diarrhea and menstruation pain. Additional uses includes its application to detoxify blood, eliminate pimples and rashes, control headaches, reduce muscular pain, or as anthelmintic, among others (de Santayana et al., 2014; de Santayana, Morales, Tardío, Aceituno, \& Molina, 2018; Escudero, 1999; Febrer et al., 2001; Romero Martín, 1998; Verde, 2008).

\subsubsection{Scientific studies}

Agrimonia eupatoria, whose phytochemical composition includes compounds of interest such as carbohydrates (Carb), T, terpenes and their derivatives, PC, vitamins and oils, among other substances, has been linked to very promising biological functions at the pharmacological level, probably associated with the presence of that compounds. Some of the bioactivities A. eupatoria produces are antitumor, antiviral, antibacterial, antioxidant, antidiabetic, analgesic, immunomodulatory, anti-inflammatory, anti-obesity, hepatoprotective, neuroprotective and healing activities, as demonstrated in numerous experimental studies, both in vitro and in vivo (Table 3, Table 4).

Starting with the antioxidant activity and the radical scavenging power of the extracts of A. eupatoria, numerous studies have demonstrated its efficacy. A study conducted on the activity of extracts against the reactive species formed during inflammation associated the antioxidant capacity observed with the presence of PC. A hydroalcoholic extract and an EA fraction were able to react with DPPH, peroxyl and hydroxyl radicals, as well as with other oxidizing species such as peroxynitrite, producing a significant radical scavenging activity and a powerful antioxidant activity. The tests carried out with polyphenolrich extracts were the ones that showed the most efficacy (up to $97.5 \%$ in the DPPH reaction, and $79.5 \%$ in the ABTS (2.2'-azino-bis(3-ethylbenzothiazoline-6-sulfonic acid)) reaction), which suggests a close relationship between the content in these compounds and the antioxidant capacity and radical scavenger (Al-snafi, 2015), as also other authors affirm that they observed a high correlation between the antioxidant function of hydroalcoholic extracts of $A$. eupatoria and their content in Pp (Muruzović, Mladenović, Stefanović, Vasić, \& Čomić, 2016). Some of the PC associated with this capacity are certain phenolic acids,

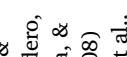

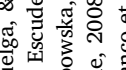

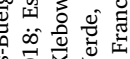

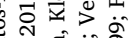

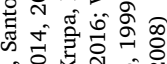

สิ

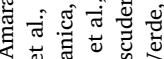

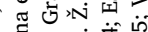

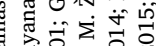

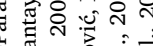

की สं สं สं

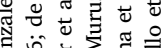

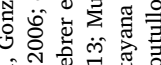

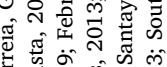

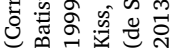

$$
\text { 这 }
$$


论

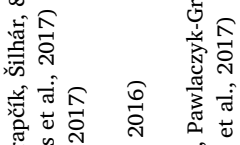

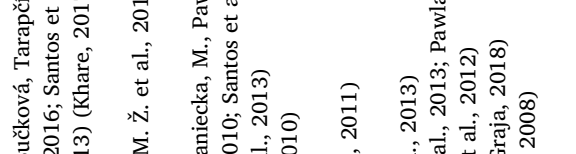

m

穿

तิ तี

离

造造

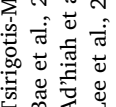

$\stackrel{\infty}{\overrightarrow{0}}$<smiles>[LiH]</smiles>

ล

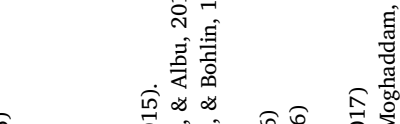

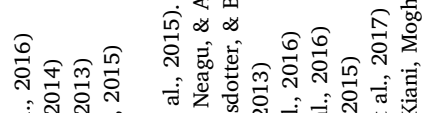

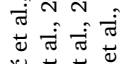

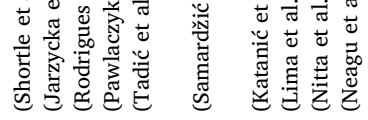

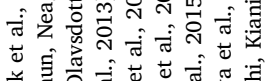

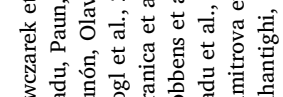

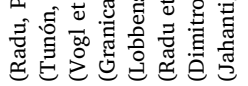

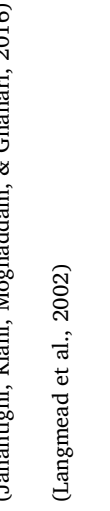

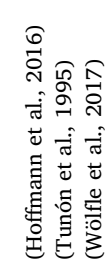

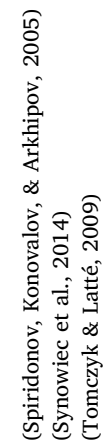

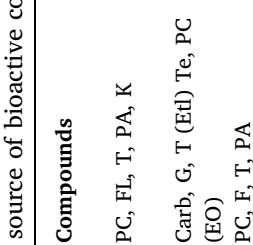

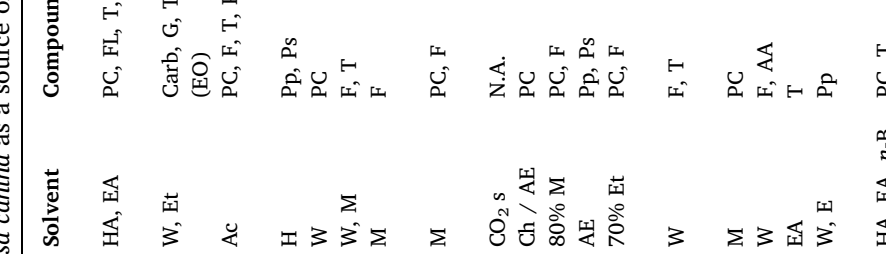

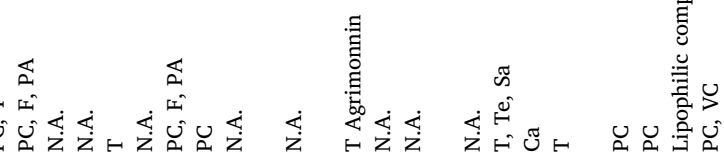
롤<smiles>C1CCCC1</smiles>

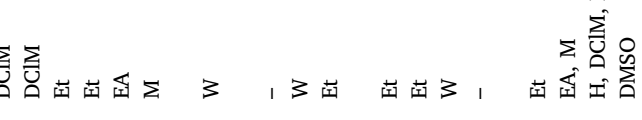

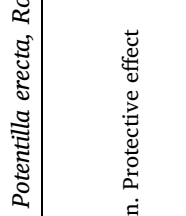

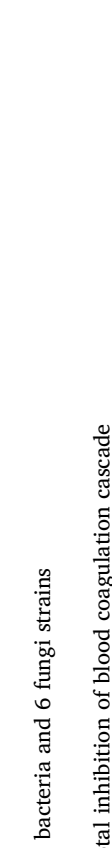

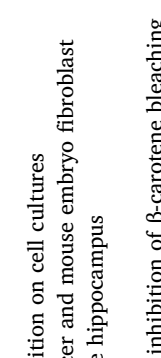

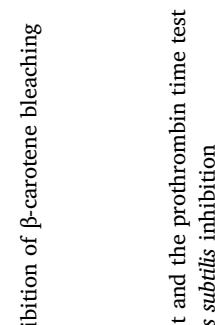

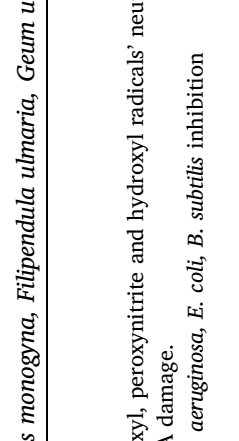

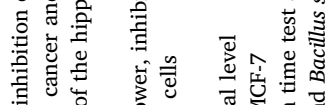

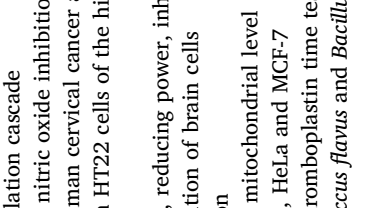

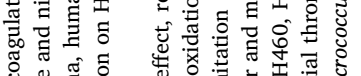

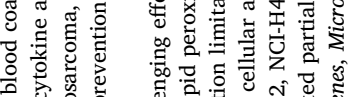

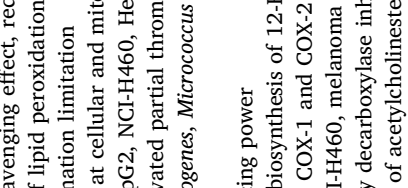

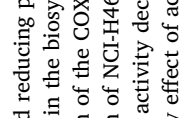

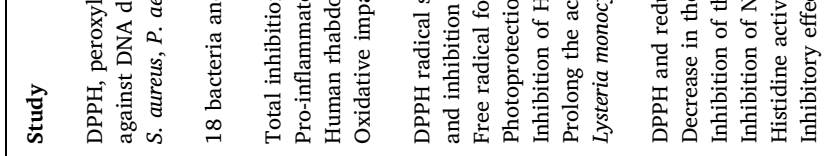

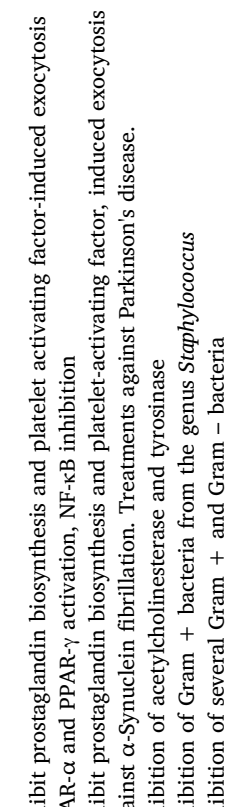

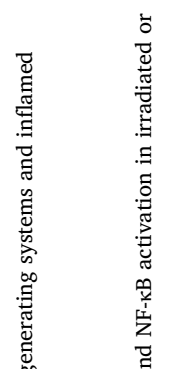

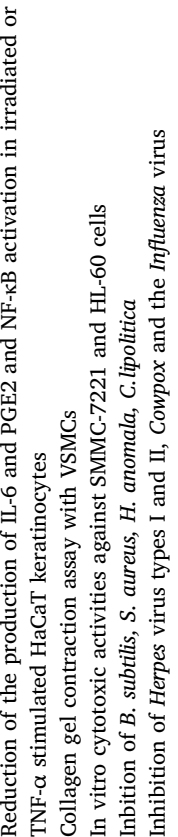

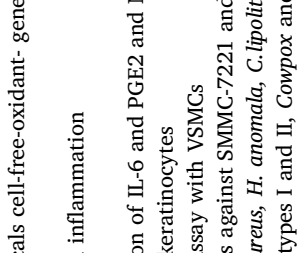

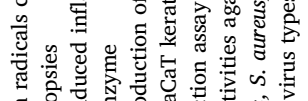

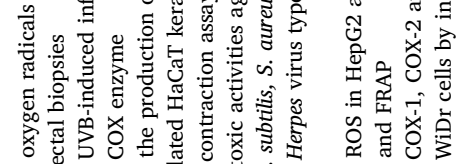

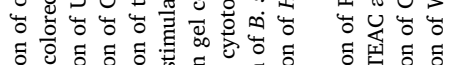

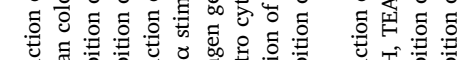

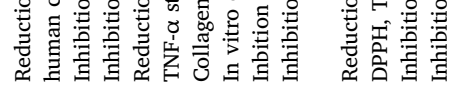

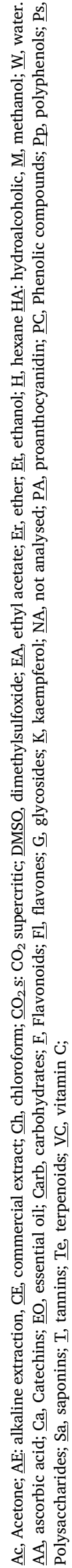

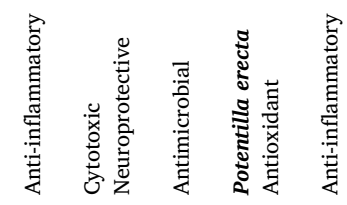

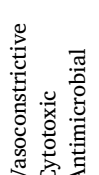

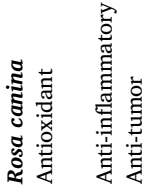

네네용 
procyanidins, F, flavan-3-ols, T, proanthocyanidins (PA), Ca, quercetin, apigenin, kaempferol $(\mathrm{K})$ and their O-glucosidic derivatives, having been reported to be up to $220.31 \mathrm{mg}$ of the total PC per gram of extract (Al-snafi, 2015; Muruzović et al., 2016).

Regarding the anti-inflammatory capacity, it was possible to inhibit the production of pro-inflammatory cytokine and nitric oxide of microglial cells in vivo by applying the aqueous extract of $A$. eupatoria (Bae et al., 2010; Yoon et al., 2012). This extract also achieved a reduction in the increase in serum aminotransferase activity, as well as in the production of tumor necrosis factor $\alpha$ (TNF- $\alpha$ ) in rats to which $10,30,100$ and $300 \mathrm{mg} / \mathrm{kg} /$ day of aqueous extract had been orally administered, in addition to imposing a chronic consumption of alcohol. It was also observed that the extract produced a protective effect against chronic liver damage caused by Et (Al-snafi, 2015). Luteolin 7-glucuronide is an active molecule that is present in the extract and is associated with the decreases in the inflammatory process, an effect probably caused by the inhibition of oxidative stress and inflammation signaling mediated by TLRs (Yoon et al., 2012). On the other hand, the ethyl extract of $A$. eupatoria managed to reduce peripheral edema in in vivo models by $43.2 \%$ (when applying a single dose) and $52.2 \%$ (when a second dose was applied). Likewise, in this study the analgesic capacity of the ethyl extract was tested, resulting in the fact that it did not produce effects of general anesthesia, but was verified by the formalin and the writhing test, which produced an inhibitory effect of $43.5 \%$ in a single dose and $49.8 \%$ when applying a second dose (Al-snafi, 2015).

The cytotoxic effects of the aqueous and methanolic extracts of $A$. eupatoria were tested in vitro tests on human RD, HeLa and mouse embryo fibroblast cell lines, using different concentrations $(6,12,24$, 48 and $96 \mu \mathrm{g} / \mathrm{mL}$ ) of the extracts, and throughout three rounds. In the results, it was observed that all the concentrations analyzed achieved the antitumor effect, although proportionally to the concentration, and that the methanolic extract achieved better results in the RD and HeLa cell lines than the aqueous extract, since the percentage growth inhibition was greater (Al-snafi, 2015; Tsirigotis-Maniecka et al., 2019). Some authors associate the antitumor activity observed in the RD and HeLa tumor cell lines with the presence of $\mathrm{F}$ and $\mathrm{T}$ in the extracts obtained from A. eupatoria (Ad'hiah, Al-Bederi, \& Al-Sammarrae, 2013).

Immunomodulatory capacity was demonstrated using a hydroalcoholic extract in the peritoneal cavity of mice, which resulted in immunostimulatory activity through the activation of phagocytes, lysozyme and peroxidase (Al-snafi, 2015).

In addition, the methanolic extract of $A$. eupatoria was shown to have neuroprotective activity by decreasing the damaging oxidative impact on HT22 cells of the mouse hippocampus produced by glutamate (Al-snafi, 2015; Lee et al., 2010). This effect was associated with various compounds present in the extract with antioxidant capacity. Among these compounds, a new flavonoid that was not previously characterized as standing out, was identified as kaempferol 3-O- $\beta$-D(2"-O-acetyl-6"-(E)-p-coumaroyl)-glucopyranoside. Other nine R known as $\mathrm{F}$ were found in the methanolic extract (Lee et al., 2010).

The antibacterial properties of the aqueous and ethanolic extracts of A. eupatoria were tested against several clinically important strains, such as Staphylococcus aureus, Pseudomonas aeruginosa and Escherichia coli. In this case, the ethanol (Et) extract was the one that showed the greatest inhibitory efficacy, specifically against $E$. coli, followed by $S$. aureus, with a $15 \mathrm{~mm}$ inhibition halo. $P$. aeruginosa was the most resistant strain to the extract. The effect of the EO of A. eupatoria was also tested, reported to be active against Bacillus subtilis (Al-snafi, 2015). In another study, 24 species of microorganisms were tested, both bacteria, for which ampicillin and tetracycline were used as control, as fungi, whose control substances were itraconazole and amphotericin B. The extract that showed the greatest antimicrobial potential was acetone (Ac) one (Mimimal Inhibitory Concentration of $4469.5 \mu \mathrm{g} / \mathrm{mL}$ for $P$. aeruginosa and $4315 \mu \mathrm{g} / \mathrm{mL}$ for $P$. mirabilis), followed by aqueous, Et and, finally, diethyl ether. Additionally, Ac extract also produced a significant inhibition of biofilm formation from $P$. aeruginosa and
Proteus mirabilis (Muruzović et al., 2016).

In addition to all these bioactivities, antidiabetic properties are also associated with $A$. eupatoria, since the aqueous extract of this plant $(1 \mathrm{mg} / \mathrm{mL})$ achieves an antihyperglycemic effect in mice, producing insulin released by the B cells of the pancreas and the stimulation of glucose transporters. Furthermore, the extract reduced symptoms of this disorder characterized as weight loss, hyperphagia and polydipsia (Al-snafi, 2015).

Other activities related to the compounds present in this plant are healing, analyzed in comparison with fucidin, which achieved complete healing in rats in 14 days, while the aqueous extract achieved it in 12 days, and the ethanolic in just 10 days; antihypertensive effect, since it manages to lower blood pressure by $40 \%$ by administering the extract intravenously in cats; uricolytic capacity, by providing infusions or decoctions at $15 \% \mathrm{w} / \mathrm{v}$ in male rats in doses of $20 \mathrm{~mL} / \mathrm{kg}$ (Al-snafi, 2015); anticoagulant function, tested in vitro using an extract of the AP of $A$. eupatoria rich in Pp and Ps that managed to totally inhibit the blood coagulation cascade and, therefore, the formation of clot plasma, at a concentration of $500 \mu \mathrm{g} / \mathrm{mL}$ (Tsirigotis-Maniecka et al., 2019); or a lipid lowering activity, observed in healthy patients who were supplied with $A$. eupatoria tea, which produced an increase in high density lipoprotein (HDL) cholesterol, also achieving an improvement in lipid profiles (Ivanova, Vankova, \& Nashar, 2013).

The European Medicines Agency (EMA) considered the properties of the herbal preparations (comminuted, tinctures or liquid extracts) and its pharmaceutical forms (comminuted for oral use or as infusion or decoction preparations for oromucosal and cutaneous uses). The uses included in the EMA report are the relief of mild diarrhoea (oral administration), mild inflammation of the mouth and throat (used for gargles), and minor skin inflammation and small superficial wounds (topic administration). It has been recommended to applied in adults and children over 12 years (EMA/HMPC/680595/2013, 2015).

\subsection{Crataegus monogyna}

\subsubsection{Traditional importance}

C. monogyna is widely distributed. It is considered native to Europe, but not in the northeastern part and the Mediterranean coast of North Africa. Roots (R), flowers (FL), leaves (L) and fruits (FR) from $C$. monogyna have different traditional uses in Iberian Peninsula (Garmendia \& Castroviejo, 1998). Tinctures, infusions, or liquid extractions are the most typical ways of application (Font Quer, 2001). Even though L and FR are not considered to possess a high nutritional value, they have been also used as food (de Santayana et al., 2014). L and FL from C. monogyna have been found to have circulatory properties, improving blood circulation and being cardiotonic and hypotensive (Font Quer, 2001). FR and FL have been used at digestive levels to prevent diarrhea and used to protect the liver in hepatitis processes. FR and R were applied in bronchitis and respiratory infections. For nervous system infections, all plant parts were mostly utilized, usually to treat insomnia, and as anxiolytic, to calm and sedate (de Santayana et al., 2014; Escudero, 1999; Franco et al., 2013; Soutullo, Muñoz, Pazó, Alonso, \& Boente, 2015; Verde, 2008).

\subsubsection{Scientific studies}

There are many studies that have been conducted of the bioactivities of C. monogyna, in which its antioxidant, cardioprotective, anticancer, anticoagulant and antimicrobial capabilities are proven, among others (Table 3, Table 4).The content of PC in this species is variable depending in the analyzed tissue, ranging from 55 in FR up to $377 \mu \mathrm{g}$ GAE/g in stems (Luís, Domingues, \& Duarte, 2011). Thus, this plant is rich in PC, such as phenolic acids, F, PAs and $\mathrm{Ca}$, as well as tocopherols, ascorbic acid (AA), $\beta$-carotene and both saturated fatty acids (hexadecanoic and tricosanoic acid) and polyunsaturated ((9Z, 12Z)-octadeca-9,12-dienoic and (9Z, 12Z, 15Z)-octadeca-9,12,15-trienoic); as well as inorganic compounds such as $\mathrm{Cu}, \mathrm{Fe}, \mathrm{Mg}, \mathrm{Mn}, \mathrm{Zn}$, etc.(Barros, 
Table 4

In vivo studies of Agrimonia eupatoria, Crataegus monogyna, Filipendula ulmaria, Geum urbanum, Potentilla erecta, Rosa canina as a source of bioactive compounds.

\begin{tabular}{|c|c|c|c|c|}
\hline Effects & Study & Solvent & Compounds & Reference \\
\hline \multicolumn{5}{|l|}{ Agrimonia eupatoria } \\
\hline Anti-inflammatory & Carrageenan-induced rat paw edema test in mice & $\mathrm{W}$ & PC & (Santos et al., 2017) \\
\hline Hepatoprotective & $\begin{array}{l}\text { Inhibition of serum aminotransferase activity and production } \\
\text { of TNF- } \alpha \text { on mice liver }\end{array}$ & $\mathrm{W}$ & N.A. & (Yoon et al., 2012) \\
\hline Antidiabetic & $\begin{array}{l}\text { Insulin release by the B cells of the pancreas and glucose } \\
\text { transporters stimulation in mice }\end{array}$ & $\mathrm{W}$ & N.A. & (Gray \& Flatt, 1998) \\
\hline Antihypertensive & $\begin{array}{l}\text { Blood pressure reduction by } 40 \% \text { when administered } \\
\text { intravenously in cats }\end{array}$ & $\begin{array}{l}\text { W, Et, Er, Ch, M, } \\
\text { Ac, DClE }\end{array}$ & N.A. & (Petkov, 1979) \\
\hline \multirow[t]{2}{*}{ Healing } & Complete healing in 12 days in rats & $\mathrm{W}$ & Carb, G, T. In Etl also & (Ghaima, 2013) \\
\hline & Complete healing in 10 days in rats & Et & Te and PC & \\
\hline Lipid lowering & $\begin{array}{l}\text { Increase in high density lipoprotein (HDL) cholesterol in } \\
\text { humans }\end{array}$ & $\mathrm{W}$ & N.A. & (Ivanova et al., 2013) \\
\hline \multicolumn{5}{|l|}{ Crataegus monogyna } \\
\hline Anti-inflammatory & $72.4 \%$ inflammation decrease in rats & $70 \% \mathrm{Et}$ & $\mathrm{Te}$ & (Tadić et al., 2008) \\
\hline Antithrombotic & Inhibition of platelet aggregation in mice & $50 \% \mathrm{Et}$ & $\mathrm{PC}, \mathrm{F}$ & (Arslan et al., 2015) \\
\hline \multirow[t]{2}{*}{$\begin{array}{l}\text { Cardioprotective and } \\
\text { antiarrhythmic }\end{array}$} & $\begin{array}{l}\text { Protective effect of myocardial dysfunction and infarction } \\
\text { occurrence in rats }\end{array}$ & $\mathrm{CO}_{2} \mathrm{~s}$ & PC, F & (Shortle et al., 2013) \\
\hline & Vasodilator effect and an inotropic effect in guinea pigs & A.E & PC, F & (Pawlaczyk-Graja, 2018) \\
\hline Analgesic & $\begin{array}{l}\text { Depression of the central nervous system. Analgesic effects } \\
\text { mediated by endogenous opioid system }\end{array}$ & $80 \% \mathrm{Et}$ & N.A. & $\begin{array}{l}\text { (Can, Özkay, Öztrk, \& Öztürk, } \\
\text { 2010) }\end{array}$ \\
\hline \multicolumn{5}{|l|}{ Filipendula ulmaria } \\
\hline \multicolumn{5}{|l|}{ Antioxidant and } \\
\hline hepatoprotective & Hepatic oxidative stress reduction in Wistar rats & M & $\mathrm{Pp}$ & (Katanić et al., 2017) \\
\hline Anti-inflammatory & Reduction carrageenan-induced paw edema in rats & M & $\mathrm{Pp}$ & (Katanić et al., 2016) \\
\hline \multirow[t]{2}{*}{ Cytotoxic } & Inhibitory effect of colorectal carcinogenesis in rats & $\mathrm{W}$ & PC & (Bespalov et al., 2018) \\
\hline & Cervix and vagina carcinoma reduction in mice & $\mathrm{W}$ & $\mathrm{F}, \mathrm{AA}$ & (Spiridonov et al., 2005) \\
\hline Gastroprotective & Acute stomach damage caused by Et reduction & $\mathrm{W}$ & $\mathrm{F}, \mathrm{T}$ & (Samardžić et al., 2018) \\
\hline Immunomodulatory & Complementary immune system activation & W & W-soluble Ps & (Olennikov et al., 2017) \\
\hline \multicolumn{5}{|l|}{ Geum urbanum } \\
\hline Hypotensive & $\begin{array}{l}\text { Intravenous injection, has been reported to produce a reduction } \\
\text { in blood pressure in cats }\end{array}$ & $\mathrm{W}$ & N.A. & (Petkov, 1979) \\
\hline \multicolumn{5}{|l|}{ Potentilla erecta } \\
\hline Vasoconstrictive & Occlusive patch test in humans & Et & N. A. & (Wölfle et al., 2017) \\
\hline Anti-diarrhoea & Reduction of diarrhea caused by rotavirus in children & $\mathrm{CE}$ & $\mathrm{T}$ & (Subbotina et al., 2003) \\
\hline Anti-ulcerogenic & Inhibition of ulcerative colitis in humans & $\mathrm{CE}$ & $\mathrm{T}$ & (Huber et al., 2007) \\
\hline Antihyperglycemic & Improvement of diabetes symptoms in mice & M & Tomentoside & (Tomczyk \& Latté, 2009) \\
\hline \multicolumn{5}{|l|}{ Rosa canina } \\
\hline Antioxidant & $\begin{array}{l}\text { Has the power to reduce pain and stiffness on human patients } \\
\text { with osteoarthritis }\end{array}$ & - & N.A. & $\begin{array}{l}\text { (Nadpal et al., 2016; Turan } \\
\text { et al., 2018) }\end{array}$ \\
\hline Anti-inflammatory & $\begin{array}{l}\text { Carrageenan-induced and PGE1-induced hind paw edema } \\
\text { models, as well as on acetic acid induced increase in a capillary } \\
\text { permeability model }\end{array}$ & W, Et & PC and VC & $\begin{array}{l}\text { (Deliorman Orhan et al., 2007; } \\
\text { Ouerghemmi et al., 2016) }\end{array}$ \\
\hline Antinociceptive & $\rho$-Benzoquinone-induced abdominal constriction test & W, Et & PC and VC & (Deliorman Orhan et al., 2007)) \\
\hline Anti-tumor & $\begin{array}{l}\text { Inhibited melanogenesis in mouse melanoma cells and guinea } \\
\text { pig skin, and could be useful as a skin-whitening agent when } \\
\text { taken orally }\end{array}$ & Et & PA & (Fujii et al., 2011) \\
\hline Anti-obese & $\begin{array}{l}\text { Inhibitory effect on the body weight gain and in the visceral fat } \\
\text { gain in mice }\end{array}$ & Ac & $T-t$ & (Ninomiya et al., 2007) \\
\hline
\end{tabular}

$\underline{\mathrm{Ac}}$, Acetone; $\underline{\mathrm{AE}}$ : alkaline extraction; $\underline{\mathrm{CE}}$, commercial extract; $\underline{\mathrm{Ch}}$, chloroform, $\underline{\mathrm{CO}_{2} \mathrm{~s}} \mathrm{\textrm {CO } _ { 2 }}$ supercritic; $\underline{\mathrm{DMSO}}$, dimethylsulfoxide; $\underline{\mathrm{EA}}$, ethyl acetate; $\underline{\mathrm{Er}}$, ether; $\underline{\mathrm{Et}}$, ethanol; $\underline{\mathrm{H}}$, hexane; $\underline{\mathrm{M}}$, methanol; $\underline{\mathrm{W}}$, water.

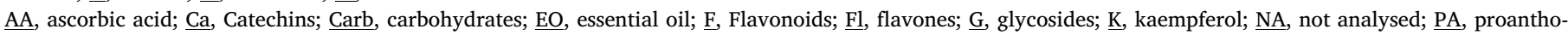

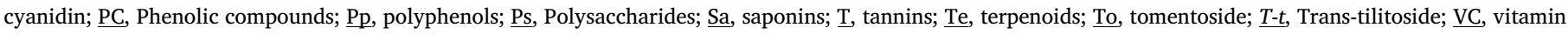
C.

Carvalho, \& Ferreira, 2011; Jarzycka, Lewińska, Gancarz, \& Wilk, 2013).

The antioxidant activity of $C$. monogyna extracts has been demonstrated in vitro using four methodologies applied to animal cell lines: DPPH radical scavenging effect, reducing power, inhibition of $\beta$-carotene bleaching and inhibition of lipid peroxidation of brain cells. All the analyzed extracts showed antioxidant capacity, being especially apparent when using the extracts of unripe FR $\left(\mathrm{EC}_{50}\right.$ between 5.42 and $20.83 \mu \mathrm{g} / \mathrm{mL}$ ), which coincides with the high amount of PC and F that contain these extracts. (Barros et al., 2011). Interestingly, in an essay on the effect of the inclusion of extracts in W-soluble gels with the intention of incorporating them into cosmetic and/or pharmaceutical preparations, the antioxidant capacity was verified, using the same methodologies mentioned above. The results showed a decrease of this property, but not significant regarding the use of isolated extracts (Barreira, Rodrigues, Carvalho, \& Ferreira, 2013).

The antioxidant compounds contained in C. monogyna also have a high potential for protection against UV radiation, both UVB and UVA, experimentally tested in vitro at the cellular and mitochondrial level, as well as high photostability (Jarzycka et al., 2013; Pawlaczyk-Graja, 2018). In addition, these compounds are associated with a cardioprotective effect, thanks to the limitation of free radical formation, reducing possible damage to the heart and the deposition of cholesterol in the arteries, as it has been demonstrated in vitro. In rat models, a protective effect of myocardial dysfunction and the occurrence of infarction was observed (Shortle, Kerry, Furey, \& Gilroy, 2013). Moreover, the extracts achieved a vasodilator effect and an inotropic effect that affected sodium-potassium $\left(\mathrm{Na}^{+} / \mathrm{K}^{+}\right)$-ATPase and that favored the $\mathrm{Ca}^{2+}$ ions transport in cardiomyocytes. In ventricular myocytes of guinea pigs, a decrease in arrhythmia was observed through a mechanism of actions similar to that of class III antiarrhythmics (Pawlaczyk-Graja, 2018), as well as a negative chronotropic effect in vitro, reducing the contraction of cardiomyocytes through the activation of muscarinic receptors. Certain $\mathrm{F}$ isolated from C. monogyna such as 
luteolin-7-glucoside, hyperoside, and rutin produced a cardioprotective effect in the hearts of isolated guinea pigs, favoring coronary flow $(186 \%, 66 \%$, and $66 \%$, respectively) and velocity of relaxation $(104 \%$, $62 \%$, and $73 \%$, respectively) in doses of $0.5 \mathrm{mmol} / \mathrm{L}$ (Nabavi et al., 2015).

Going deeper into the content of the extracts, (Pawlaczyk-Graja, 2018) polyphenol-polysaccharide conjugates were isolated and characterized by using various spectrophotometric methods such as GLCMS, FT-IR and NMR techniques. These were Pp matrices, including some $\mathrm{F}$ and poorly esterified Ps rich in galacturonic acid, capable of increasing blood clotting time with very low concentrations $(31.25 \mu \mathrm{g} /$ $\mathrm{mL}$ ), as verified in vitro, although the FL extract was the one that showed an action with greater selectivity (Pawlaczyk-Graja, 2018). The antithrombotic effect of the methanolic extract was tested in mouse tail models injected with a carrageenan, using heparin as the control substance. Extract doses of between 200 and $300 \mathrm{mg} / \mathrm{kg}$ were the most effective, achieving an inhibition of platelet aggregation with a high significance (Arslan, Bektas, Bor, \& Sener, 2015; Nabavi et al., 2015).

The oral administration of $C$. monogyna extracts to rats with edemas demonstrated the anti-inflammatory effect of this plant, even surpassing what was produced by indomethacin, a drug used as a positive control, since a $72.4 \%$ decrease in inflammation was reported when the extract was used, compared to $50 \%$ achieved by the control. This activity is associated with the presence of triterpenes, especially cycloarterol (Nabavi et al., 2015).

The antitumor capacity of $C$. monogyna extracts, highly related to the antiproliferative and the apoptotic effect of PC, was tested in four human tumor lines: NCI-H460, HepG2, HeLa and MCF-7, resulting in extracts obtained from FL being the most effective. HPLC-DAD-ESI/MS analyzes of the extracts revealed a predominance of $\mathrm{F}$ (Rodrigues et al., 2012). An interesting fact is that, in addition to not producing toxicity in non-tumor cells, the aqueous extract of $C$. monogyna is capable of exerting a protective effect against the toxicity caused by doxorubicin, a broad-spectrum chemotherapeutic drug whose use has been restricted (Shalizar Jalali \& Hasanzadeh, 2013).

The antibacterial activity produced by the extracts of C. monogyna is moderate, especially against Gram-positive bacteria, such as Lysteria monocytogenes, Micrococcus flavus and B. subtilis (Nabavi et al., 2015).

Another capacity that deserves to be highlighted is the regulation of the central nervous system, since it depresses its functionality as observed in mice, whose locomotor activity decreased after the administration of $C$. monogyna. An analgesic effect associated with the activation of opioid receptors was also observed; as well as a gastro-protective function comparable to that of ranitidine in rat models (Nabavi et al., 2015).

The EMA report for Crataegus monogyna offers a wide range of optional herbal preparations and pharmaceutical forms (comminuted/ powdered, dry and liquid extracts using different extraction ratios and solvents, such as ethanol, methanol or sweet wine, juices, and tinctures). Leaf and flower preparations have been associated with the relief of nervous-based temporary heart complaints, such as palpitations, but it requires the previous exclusion of medical major and serious conditions. Same preparations may also relieve mild symptoms of mental stress and to aid sleep. Their use is contemplated for adults and children over 12 years (EMA/HMPC/159076/2014, 2016).

\subsection{Filipendula ulmaria}

\subsubsection{Traditional uses}

F. ulmaria is a common and widespread plant, native to Europe and Western Asia, while it has also been introduced but naturalized to North America, including some states from the United States (US) and Canada, where it has become naturalized. Flowered apexes from $F$. ulmaria, preferably collected when flowering is beginning, are consumed as an infusion, decoction, dry or liquid extract, tincture or syrup (Escudero, 1999). Antiseptic, analgesic, anticoagulant, anti-inflammatory, antipyretic, anti-rheumatic, astringent, diaphoretic and diuretic properties have been associated with this species (Escudero, 1999; Franco et al., 2013; Rivera \& Obón, 1998). Pharmaceutical industries utilized this plant as a precursor to aspirin since it contains salicylic acid. In addition, it has been applied for the treatment of cystitis and rheumatic pain (Font Quer, 2001). L and FL of F. ulmaria have been also used for aromatizing soups or wine and beers, respectively. It is a useful resource of ocher colors and Eos in cosmetics (Escudero, 1999).

\subsubsection{Scientific studies}

F. ulmaria is known to possess many biological activities, among which antioxidant, anti-inflammatory, antimicrobial and anti-proliferative capacities stand out (Katanić et al., 2017) (Tables 3 and 4). Another interesting property that has been associated with this MP is a healing function. PC are the constituents of $F$. ulmaria that mostly related to bioactive potentials, and can be divided into three main groups: phenolic acids (salicylic acid, gallic acid, ellagic acid, salicylaldehyde, etc.), $\mathrm{F}$ and their $\mathrm{G}$ (K, rutoside, epicatechin, $\mathrm{Ca}$, quercetin, spiraeoside, apigenin, hyperoside, astragalin, etc.), and T (rugosin A, B1, B2, D, E1 and E2, tellimagrandin I and II, etc.) (Katanić et al., 2016).

The antioxidant properties of $F$. ulmaria extracts have been reported and demonstrated by many studies (Neagu, Paun, Albu, \& Radu, 2015; Olennikov, Kashchenko, \& Chirikova, 2017). A recent investigation analysed the radical scavenging activity of lyophilized FL infusions, in which the potential for in vitro neutralization of DPPH and $\mathrm{OH}$ radicals was evaluated, as well as the reducing power through the FRAP assay, obtaining IC I0 $_{50}$ values of $8.45 \mathrm{ug} / \mathrm{mL}$ for DPPH and a FRAP value of $4.46 \mathrm{mmol} \mathrm{Fe} 2^{+} / \mathrm{g}$. However, the results suggest that this extract has no potential to neutralize OH radicals (Samardžić et al., 2018). Taking into account the aerial part and the root of F. ulmaria, the methanolic extracts of these parts achieved potent antioxidant effects demonstrated in vivo Wistar rats, since the administration of such extracts for 10 consecutive days reduced the hepatic oxidative stress induced by cisplatin, a drug used in antitumor therapies and that of which is related to numerous adverse effects. An increase in the activities of catalase and superoxide dismutase, and a reduction of lipid peroxidation and suppression of DNA damage in normal cells was observed (Katanić et al., 2017).

Regarding the anti-inflammatory activity of the extracts of $F . u l$ maria, results obtained both in vitro and in vivo show an important potential. FL extracts achieved a moderate effect of the activation of PPARs (Katanić et al., 2016). The infusion of lyophilized FL studied $e x$ vivo in human platelets achieved a decrease in the biosynthesis of 12HETE and PGE2 with IC ${ }_{50}$ values of 3415 and $6768 \mu \mathrm{g} / \mathrm{mL}$, respectively (Samardžić et al., 2018). The inhibition of NF-кB achieved by extracts from other plant parts of $F$. ulmaria was potently significant (Katanić et al., 2017). Likewise, it was demonstrated that the extracts of $F$. ulmaria managed to reduce the production of cytokines in vitro, IL-1ß, IL6 and TNF- $\alpha$, in addition to the inhibition of the activity of 15-LOX. The tests carried out with the extracts $(50 \mu \mathrm{g} / \mathrm{mL})$ of the AP and R of $F$. ulmaria achieved a significant inhibition of COX-1 and COX-2, being the predominant inhibitory effect of the extract of the AP (62.84\% COX-1 inhibition and $46.43 \% \mathrm{COX}-2$ inhibition), and, therefore, comparable to the inhibitory values achieved using the control substances, indomethacin and NS-398 at concentrations of $1.25 \mu \mathrm{M}$ and $5 \mu \mathrm{M}$, respectively (Katanić et al., 2016). In in vivo trials in rats, in which carrageenan had been injected, causing tail edema, it was observed that the administration of $100 \mathrm{mg}$ of AP extract and $200 \mathrm{mg}$ of R extract per $\mathrm{kg}$ of body weight, was capable of significantly reducing inflammation, thereby achieving the maximum peak of action at $24 \mathrm{~h}$ (Katanić et al., 2016).

Immunomodulatory properties of $F$. ulmaria have also been demonstrated. W-soluble Ps obtained from F. ulmaria FL have the ability to activate the complementary immune system in a dose-dependent manner. This system is related to the beginning of inflammatory processes, leukocyte activation and degranulation of basophils and mast 
cells. (Olennikov et al., 2017).

Similarly, the hepatoprotective and neuroprotective properties of $F$. ulmaria have been investigated. The hepatoprotective capacity of an Et extract was tested in vivo, resulting in the aforementioned beneficial action, which was closely related to the antioxidant properties of the plant, as well as the ability to stabilize membranes. The characterization by LC-DAD-MSn of the extracts of AP and R allowed the broad phenolic composition present in this plant to be elucidated, among which the quercetin stands out, being identified in both plant parts, and related to strong antioxidant properties (Katanić et al., 2017). The neuroprotective capacity was tested through the inhibitory effect of the AChE and tyrosinase enzymes, using aqueous and ethanolic extracts. At concentrations of $3 \mathrm{mg} / \mathrm{mL}$, ethanolic extract achieved a greater inhibition of AChE, $98.3 \%$ versus an inhibition of $77.03 \%$ produced by the aqueous extract. In the case of tyrosinase, the inhibitions achieved showed fewer differences: $90.65 \%$ for ethanolic extract and $87.88 \%$ for $\mathrm{W}$ extract. The PC associated with this bioactivity were Pp such as quercetin and rutin, and chlorogenic acid (Neagu et al., 2015).

On the other hand, the anti-tumor effects of $F$. ulmaria extracts, such as those produced by FL extracts, which inhibit the proliferation of NCI$\mathrm{H} 460$ tumor cells and cause an increase in p21 levels (at G1-checkpoint cyclin-dependent kinase inhibitor) have also been reported. In addition, concentrations between 10 and $50 \mu \mathrm{g} / \mathrm{mL}$ of the ethanolic extracts of $F$. ulmaria produced cytotoxicity in Burkitt lymphoma cell lines (Lima et al., 2014). Additionally, the inhibitory activity of a decoction of $F$. ulmaria in colorectal tumor processes was evaluated in vivo in female rats to which carcinogenesis had been induced using methylnitrosourea. A potent inhibitory effect of colorectal carcinogenesis was observed, probably related to the anti-inflammatory potential of $F$. ulmaria extracts in certain stomach and intestinal pathologies (Bespalov et al., 2018). Another study that corroborates the antitumor action of the extracts of $F$. ulmaria was performed in mice with cervical dysplasia, to which extracts obtained by decoction of FL were locally administered. The extracts were able to reduce the frequency of occurrence of carcinoma of the cervix and vagina, induced by 712-dimethyl-benz (a) anthracene (Lima et al., 2014).

Other effects related to $F$. ulmaria extracts are gastroprotective capacity, demonstrated in animal models with acute stomach damage caused by ethanol, to which oral infusions of lyophilized FL (100-300 mg/kg) were orally administered (Samardžić et al., 2018). Likewise, some PC belonging to the group of T, found in EA extracts from $\mathrm{P}$ of $F$. ulmaria, such as rugosin D, rugosin A, rugosin A methyl ester and tellimagrandin II, were able to significantly inhibit histidine activity decarboxylase, an enzyme related to the symptoms of many allergies and stomach ulcers (Nitta et al., 2013). F. ulmaria tea intake is also associated with an inhibitory effect of the enzymes amylase and $\alpha$ glucosidase, as well as the formation of advanced glycation end products (Olennikov et al., 2017).

The EMA report for Filipendula ulmaria includes herbal and pharmaceutical forms (comminuted for flowers and herbs, and powdered or tinctures with ethanol for the herb). They are recommended for the relief of cough and cold symptoms, as well as for pain and inflammation. Due to the lack of enough clinical safety data, the use of these herbal/pharmaceutical preparations is not recommended during pregnancy and lactation and in children and adolescents under 18 years of age (EMA/HMPC/434892/2010, 2013).

\subsection{Geum urbanum}

\subsubsection{Traditional use}

Geum urbanum is widely extended throughout Europe, where it can reach elevations up to $2100 \mathrm{~m}$ over sea level. It is also considered to be native to North Africa (Algeria, Morocco, Tunisia), and temperate Asia from Anatolia, Syria and Caucasian areas up to further occidental and central zones. References about Iberian traditional uses of Geum urbanum are not easily found. Nevertheless, scientific references from other geographical areas point out that all parts of the plant have antiinflammatory properties. Mostly, infusions of dried or fresh FL and R are valued since they were demonstrated to be astringent, anticholesterolemic, antihypertensive, sedative and haemostatic. Mouth, throat and gastrointestinal tract affections, such as loss of appetite or diarrhea have been treated using infusions. In addition, these infusions can be externally applied to wash hemorrhoids, genital discharges and skin infections (Al-Snafi, 2019; Singh et al., 2019).

\subsubsection{Scientific studies}

G. urbanum has been used for a long time in folk medicine due to its astringent and antiseptic properties. More recent studies have shown that its traditional use makes sense, considering G. urbanum is rich in PC like gallic, caffeic and chlorogenic acids, and also eugenol, carotenoids, $\mathrm{F}, \mathrm{T}$ and vicianose sugar, which is a very rare disaccharide that can be isolated from its R (Al-Snafi, 2019; Owczarek, Gudej, \& Olszewska, 2015) (Table 3, Table 4). Other studies also found ellagitannins and procyanidins located in the R of G. urbanum and the EO extracted from the AP have also been studied (Al-Snafi, 2019; Dimitrova et al., 2017).

Total phenolic acids, $\mathrm{F}$ and PA content were evaluated in aqueous extract and ethanolic G. urbanum extracts. In the first, total phenolic acids were $768.2 \mathrm{GAE} / \mathrm{l}$, total $\mathrm{F}$ were $14.7 \mathrm{mg} \mathrm{RE} / \mathrm{l}$ and PA were $37.5 \mathrm{mg} \mathrm{CE} / \mathrm{L}$, whereas in the second, total phenolic acid was 1261.5 were mg GAE/l, a total flavonoid, $49.9 \mathrm{mg} \mathrm{RE} / 1$ and PA, $60.1 \mathrm{mg} \mathrm{CE} / \mathrm{L}$ (Al-Snafi, 2019). Ellagitannins and gallotannins are also known constituents of G. urbanum, and ellagic acid is also present. Ellagic acid is a potent antioxidant properties with beneficial properties to human health, such as hepatoprotective, cardioprotective, and chemopreventive effects (Owczarek, Olszewska, \& Gudej, 2014). Another potent antioxidant detected in high amounts is gallic acid, which also showed antiviral activity (Owczarek et al., 2014).

The antioxidant activity of different $G$. urbanum extracts has been demonstrated in several studies. (Mantle, Eddeb, \& Pickering, 2000) analysed a hydroalcoholic extract of G. urbanum L, demonstrating a powerful antioxidant effect through the ABTS assay, with values of $1.67 \mathrm{mmol}$ Trolox/equivalent/mg of dry weigh. Hydromethanolic extracts of the underground and AP were evaluated trough FRAP, DPPH, and linocelic acid oxidation assays. The assays had similar antioxidant activities, which the author correlates with the presence of PC (Owczarek et al., 2015). Aqueous and Et extract also showed a remarkable scavenging activity against 2, 2-diphenyl-1- picrylhydrazyl with values of $\mathrm{IC}_{50} 7.8 \mu \mathrm{g} / \mathrm{mL}$ and $\mathrm{IC}_{50} 1.3 \mu \mathrm{g} / \mathrm{mL}$, respectively (AlSnafi, 2019).

Regarding anti-inflammatory properties, Geum urbanum was able to inhibit prostaglandin biosynthesis and platelet-activating factor-induced exocytosis in vitro tests. Different extracts, in a concentration of $10 \mathrm{mg} / \mathrm{mL}$, were tested on PPAR- $\alpha$ and PPAR- $\gamma$ activation as well as on $\mathrm{NF}-\kappa \mathrm{B}$ inhibition. The best results were obtained with the dichloromethane extraction, which possessed moderate to strong effects (Al-Snafi, 2019).

G. urbanum was also tested trough $\mathrm{R}$ infusions and decoctions. These extractions have been used externally for reducing gingivitis (bleeding and inflammation of gums), and other membranes mucous membranes (Granica et al., 2016). This action is attributed to its high content in Gemin A. This compound significantly affects the functions of stimulated neutrophils by reducing the surface expression of $\mathrm{CD} 11 \mathrm{~b}$, and inhibiting the release of reactive oxygen species, and proteases (elastase, matrix metallopeptidase-9), chemokines and cytokines (interleukins IL-8, IL-1 $)$, besides it also stimulates the release of TNF- $\alpha$, which may be one of the stimulators of the apoptosis of neutrophil cells (Granica et al., 2016).

G. urbanum extracts were also tested for their in vitro neuroprotective effect via the inhibition of AChE and tyrosinase. The aqueous extract had an AChE inhibitory activity of $27.03 \% ; 36.48 \%$ and $79.11 \%$ at concentration of $0.75 \mathrm{mg} / \mathrm{mL}, 1.5 \mathrm{mg} / \mathrm{mL}$ and $3 \mathrm{mg} / \mathrm{mL}$ respectively. The $\mathrm{IC}_{50}$ was $2.3 \mathrm{mg} / \mathrm{mL}$ for this extract. For the ethanolic extracts, 
AChE inhibitory activities were 54.74; 73.53 and 86.77 for the same concentrations. The $\mathrm{IC}_{50}$ was $0.5 \mathrm{mg} / \mathrm{mL}$. Even though all concentrations of the aqueous extracts inhibited tyrosinase in more than $50 \%$, ethanolic extracts were more potent than the aqueous ones (Al-Snafi, 2019).

Furthermore (Dimitrova et al., 2017), also studied the antimicrobial potential of extracts from $G$. urbanum against Gram-positive. EA fractions from the AP and R had a MIC of $78 \mu \mathrm{g} / \mathrm{mL}$ and $156 \mu \mathrm{g} / \mathrm{mL}$, respectively, and inhibited the visible growth of the bacteria tested, suppressing their respiratory activity up to $26.2-28.9 \%$. The minimal bactericidal concentration calculated was $625 \mu \mathrm{g} / \mathrm{mL}$ (Dimitrova et al., 2017).

The presence of Lewy bodies and Lewy neuritis is thought to be a major pathological hallmark of Parkinson's disease and is also linked to the disease's development. These aggregations of protein primarily consist of fibrillated $\alpha$-Synuclein; and for now, there is no treatment available targeting stabilization of $\alpha$-Synuclein in its native state. In the study of (Lobbens et al., 2016), an ethanolic extract of G. urbanum was found to inhibit $\alpha$-Synuclein fibrillation in a concentration-dependent way and to partly disintegrate preformed $\alpha$-Synuclein fibrils.

Finally, in vivo studies performed in cats have shown that a $20 \%$ aqueous decoction of $G$. urbanum, administered by intravenous injection, produced a reduction in their blood pressure (Al-Snafi, 2019).

\subsection{Potentilla erecta}

\subsubsection{Traditional use}

$P$. erecta is aEuroasiatic plant widely spread throughout Europe, Caucasus, Anatolia and Western Siberia, up to 2,300 m above sea level. It can be also found in the northwest parts of Africa, Azores and Madeira and, as $F$. and $P$. erecta, it has been naturalized in North America (Guillén \& Rico, 1998). R from P. erecta are usually applied orally as an infusion to treat diarrhea and intestinal colic, due to its astringent properties. The decoction of the same part of plant can be topically used for skin infections and also hemorrhoids (Font Quer, 2001). P. erecta is also considered to be hypotensive, improve blood circulation and to control urinary incontinence, menorrhagia, and arthritic pain (Febrer et al., 2001; Tobyn, Denham, \& Whitelegg, 2011).

\subsubsection{Scientific studies}

$P$. erecta is an interesting plant with different confirmed bioactivities, such as antioxidant, antimicrobial, anti-inflammatory and antidiarrhea properties (Table 3, Table 4). These properties are mostly associated with the presence of different molecules like $\mathrm{F}$, triterpenoids and phenolic acids, which are usually extracted from the $\mathrm{R}$ and rhizomes of this plant, being the most abundant T, with 15 to $25 \%$ of dry weight. The rhizome of this plant is rich in PA and hydrolysable T, mostly agrimoniin, a dimeric ellagitannin that represents about $2 \%$ of the dry mass (Wölfle, Hoffmann, Haarhaus, Rao Mittapalli, \& Schempp, 2017). These compounds are thought to be beneficial for human health due to their antioxidant proprieties and because PA are capable of complex macromolecules and metal ions. In addition, they have been proven to play an important role in the anti-inflammatory activity of several diseases, probably due to their scavenging and antioxidant activities (Mari, Eletto, Pizza, Montoro, \& Piacente, 2013).

A $P$. erecta rhizome extract showed antioxidant effects in cell-freeoxidant- generating systems and in inflamed human colorectal cells, reducing the production of oxygen radicals (Tomczyk \& Latté, 2009).

A study from (Wölfle et al., 2017) determined the anti-inflammatory activity of $P$. erecta in irradiated HaCaT keratinocytes, by measuring the formation of IL- 6 and PGE2. They also analysed the effect on TNF- $\alpha$ induced NF-KB activation, both tests having demonstrated great results in the reduction of inflammation. In this study, P. erecta also showed a blanching effect comparable to hydrocortisone, that it is thought to be partly attributable to a scavenging effect of NO and inhibition of eNOS. However, compared to glucocorticoids, $P$. erecta was not able to cause nuclear translocation of the glucocorticoid receptor in HaCaT cells.

In a different study, extracts from $P$. erecta combined with an hydrolysable tannin Agrimonnin, known to be a potent radical scavenger, were able to reduce the inflammation caused by UVB-rays in HaCaT keratinocytes through the inhibition of cyclooxygenase-2 in a dosedependent manner (Hoffmann et al., 2016; Wölfle et al., 2017). A further experiment demonstrated that the extracts produced a dose-dependent inhibition of UVB-induced inflammation in a in vivo model (Hoffmann et al., 2016).

The cytotoxic properties of $P$. erecta have been evaluated. (Tomczyk \& Latté, 2009) studied the crude extract of $P$. erecta rhizome in $40 \% \mathrm{Et}$ and determined that concentrations of 10 and $50 \mu \mathrm{g} / \mathrm{mL}$ were able to inhibit lymphoma cell growth. They also studied the effect of the extract on the herpes virus types I and II in vitro and it revelled a moderate antiviral effect, as well as its cytotoxic activity against Cowpox and the influenza virus type A2 (Tomczyk \& Latté, 2009).

(Synowiec, Gniewosz, Bączek, \& Przybył, 2014) evaluated the antibacterial proprieties of an aqueous extract of $P$. erecta rhizome and it displayed an inhibiting effect against Gram-positive bacteria, like $B$. subtilis ATCC 6633 and S. aureus ATCC 25923, and also against yeastlike Hansenula anomala R 26 and Candida lipolitica KKP 322.

As mentioned before, $P$. erecta presents anti-diarrhoea properties, which have been corroborated by different studies. The oligomeric and polymeric flavan-3-ols (also known as condensed T or PA) have shown therapeutic properties in the treatment of diarrhoea, by complexing secretory compounds such as cholera toxin. Moreover, they also created an unspecific complexation of mucosal proteins in the gut, forming a protective layer and inhibiting the intestinal motility associated with the secretory compounds (Tomczyk \& Latté, 2009). This action was tested with a rhizome dry extract and the results showed a high efficacy in the therapy of children's diarrhoea due to Rotavirus. The treatment ensured a shorter duration of the diarrhoea (three days) compared with the placebo group (five days). In the treated group, $40 \%$ of the children were diarrhoea free $48 \mathrm{~h}$ after admission to the hospital. In the placebo group this only happened to $5 \%$ of the children, which leads the authors to assume that there is an interaction between the $\mathrm{T}$ and the Rotavirus proteins that contributes to the high efficacy of this extract, but they also admit that another unknown ingredient might also be involved (Tomczyk \& Latté, 2009).

Another use for the $P$. erecta extract is in the treatment of active ulcerative colitis. Sixteen patients were treated with the extract for three weeks with a dosage of $2,400 \mathrm{mg}$ /day, resulting in a significant decline in the colitis activity index (Tomczyk \& Latté, 2009).

Besides, $P$. erecta even decreased the biochemical indices of lipid metabolism in the blood, specifically of malonaldehyde and endogenic lipids, after three administrations of a spirituous tincture from the rhizome, on albino rats under normal physiological conditions. The tincture was administered intragastrically for 14 days at 0.05 and $0.1 \mathrm{~mL}$ per $100 \mathrm{~g}$ of the animals' body weight (Tomczyk \& Latté, 2009).

\subsection{Rosa canina}

\subsubsection{Traditional uses}

$R$. canina belongs to Europe, Caucasus, central area of Asia (Pakistan, Afghanistan, Iran, Iraq, Anatolia, Syria, Lebanon, and Palestine), and the northwest of Africa, Canary Islands and Azores Islands. Like the last three species, it was naturalized in North America, as well as in Chile, and in Southern Australia. Different parts of Rosa canina are used and are recommended to be collected during diverse seasons. Petals (P) should be collected before the flower blooms, rose hips $(\mathrm{RH})$ by the end of summer or autumn, and L during spring. $\mathrm{RH}$ are the most used part of Rosa canina and can be infused, decocted, extracted as a liquid, tinctured or consumed as syrup. Anti-diarrheic, astringent, healing, depurative, diuretic, venotonic, and vitamin properties are associated with this species. Respiratory infections, such as a cough, cold or sore throat, have been treated with RH infusions, which 
can be mixed with other plants (Origanum spp., Laurus nobilis, Ficus carica and Citrus limon). RH are well-known to be a vitamin C (VC) source, so infusions are used for treating anemia and to control diarrhea. Jams using RH and P are valued for their high vitamin content. In gastronomy, $\mathrm{P}$ are also a decoration element in salads. $\mathrm{L}$ have been used as tea substitute, $\mathrm{L}$ and dried hip roses have been added to beverages to provide aroma, color and taste. Rose water, which has been described as a collyrium, has been widely applied in cosmetics for providing aroma or color as well as for its astringent properties. Indirect uses of this plant can be applied, one example is the honey obtained from rose P (Blanco, Macia, \& Morales, 1999; Escudero, 1999; Verde, 2008)

\subsubsection{Scientific studies}

Numerous studies have tried to determine the mechanisms of the action of $R$. canina of the different antioxidant, anti-inflammatory and diuretic properties (Tables 3 and 4). The anti-inflammatory activities observed in vitro were related to the inhibition of pro-inflammatory enzymes such as cyclogenases, lipoxygenases, cytokines, chemokines, metalloproteases, nitric oxide synthase, and related stress factors such as NF-kB or C-reactive protein levels (Gruenwald, Uebelhack, \& Moré, 2019). Among its different constituents, PC and VC stand out, due to their interesting properties (Cosmulescu, Trandafir, \& Nour, 2017; Gruenwald et al., 2019). The nutritional content of $R$. canina has been described and characterized as follows: $643.38 \pm 138.4$ of ascorbic acid, $28.78 \pm 2.07$ of carotenes, $13.28 \pm 0.85$ of total sugars and $0.36 \pm 0.03$ of protein (all the values are expressed in $\mathrm{mg}$ per $100 \mathrm{~g}$ of fresh weigh) (Rosu et al., 2011). Regarding antioxidant properties, several compounds with high antioxidant proprieties have been identified in R. canina extracts: PC, such as quercitrin, gallic, and protocatechuic acids, and also VC. These compounds are known for their potent antioxidant radical scavenging effects and their capacity for neutralizing reactive oxygen and nitrogen species (Gruenwald et al., 2019). EA extracts of this plant have a total phenolic content of $197 \mu \mathrm{g}$ $\mathrm{GAE} / \mathrm{mg}$ of dry content. Methanolic extracts have shown a wide variety of results depending on the pre-treatment of the sample. Fresh biomass displayed a lower phenolic amount, 7.27 $\mu \mathrm{g} \mathrm{GAE} / \mathrm{mg}$, than when using dry biomass which concentration was estimated in $255 \mu \mathrm{g} \mathrm{GAE} / \mathrm{mg}$ (Cosmulescu et al., 2017; Ouerghemmi et al., 2016). The antioxidant properties of the more concentrated extracts, both the EA and the methanolic, were tested by using different methods. The methanolic extract showed better results for the TEAC, FRAP and DPPH assays, while the EA showed good results for the ORAC assay (Ouerghemmi et al., 2016). This activity has also been studied in vitro, on HepG2 and SH-SY5Y cells against intracellular reactive oxygen species (Fetni, Bertella, Ouahab, Martinez Zapater, \& De Pascual-Teresa Fernandez, 2017).

(Gruenwald et al., 2019) also determined that $R$. canina has different anti-inflammatory effects: reduces the pro-inflammatory molecules and C-reactive protein levels, diminishes NF-kB signalling, inhibits pro-inflammatory enzymes, including COX1 and 2, 5-LOX and iNOS, reduces the chemotaxis and chemoluminescence of polymorphonuclear cells, and inhibits pro-inflammatory metalloproteases. The anti-inflammatory properties of a $R$. canina ethanolic extract were demonstrated in vivo models. The extract was able to significantly inhibit the inflammation in the studied models: carrageenan-induced and PGE1-induced hind paw edema models, on an acetic acid-induced increase in a capillary permeability model and on a pain-model based on the inhibition of p-benzoquinone-induced in writhing mice (Deliorman Orhan, Hartevioğlu, Küpeli, \& Yesilada, 2007). Besides, it has been reported that in humans, $R$. canina has the power to reduce pain and stiffness in patients with osteoarthritis (Ouerghemmi et al., 2016).

Numerous studies have reported good cytotoxic activity against HeLa, MRC-5, human colon (HT-29) and breast (MCF-7) cancer cells as well anti-proliferative effects on human colon cancer (Caco-2) cells by increasing the number of apoptotic cells and cell cycle arrest at the $S$ phase (Nadpal et al., 2016; Turan et al., 2018). Through the inhibition of tyrosinase, ethanolic extract of $R$. canina has cytotoxic effect on mouse melanoma. This extract also has a selective cytotoxic effect on WiDr cells compared with normal colon cells, inducing cell cycle arrest at the $\mathrm{S}$ phase and apoptosis via reduced matrix metalloproteinases. In addition, an inhibition in the expression of telomerase was observed in WiDR cells at 48 and $72 \mathrm{~h}$ of treatment (Turan et al., 2018).

(Fujii, Ikeda, \& Saito, 2011) suggested that PA present in orally administered $R$. canina extract were the compounds responsible for the skin pigmentation's inhibition of tyrosinase activity on the skin of brown guinea pigs.

Finally, different works point to $R$. canina as a source of biomolecules which may improve nutritional pathologies. A study conducted on mice demonstrated the anti-obese properties of $R$. canina. Acetone extracts of FR (with a concentration of $50 \mathrm{mg} / \mathrm{kg} / \mathrm{dw}$ ) and seeds (with a concentration of 12.5 and $25 \mathrm{mg} / \mathrm{kg} / \mathrm{dw}$ ) were tested on mice. These extracts were found to have a substantial inhibitory effect on weight gain and in visceral fat gain without affecting the food intake in mice for two weeks after the administration of the extracts. The study attributed these proprieties to trans-tiliroside $(0.1-10 \mathrm{mg} / \mathrm{kg} / \mathrm{d})$ present in the $R$. canina extract, and this compound also significantly reduced blood glucose levels after glucose loading $(1 \mathrm{~g} / \mathrm{kg})$ in mice (Ninomiya et al., 2007). W fractions of $R$. canina, mostly containing vitamins, carotenoids, flavonoids, tannins, sachharides and pectins, were demonstrated to have hypoglycaemic activity in induced diabetic rats. The administration of these extracts triggered an increment in the number of active islets of pancreas while reducing necrotic ones islets. Another functions related with the consumption of $R$. canina were the prevention of ulcer formation and anti-diarrheal. The antioxidant effect of extracts obtained from this plant has been also displayed to reduce the peroxidation of lipids or unsaturated fatty acids which action in hepatic and renal tissues have demonstrated to attenuate their associated diseases (Ayati et al., 2018; Mármol, Sánchez-de-Diego, JiménezMoreno, Ancín-Azpilicueta, \& Rodríguez-Yoldi, 2017).

\section{Conclusion}

Although modern medicine has almost replaced the traditional use of plants, they are still a source of healing. The numerous studies compiled in this review confirm the knowledge obtained from the trial and error of thousands of years: the six plants selected possess compounds with many health benefits that justify their use in traditional medicine. Understanding the knowledge that has been revealed to us through popular wisdom is important, since this information may be the key to the development of different drugs, foods and other products in the future. Thus, conducting more studies about the phytochemical composition and the mechanisms of the actions of the compounds is essential.

\section{CRediT authorship contribution statement}

P. Garcia-Oliveira: Conceptualization, Methodology, Formal analysis, Investigation, Visualization, Supervision. M. Fraga-Corral: Conceptualization, Methodology, Formal analysis, Investigation, Visualization, Supervision. A.G. Pereira: Conceptualization, Methodology, Formal analysis, Investigation, Visualization, Supervision. C. Lourenço-Lopes: Conceptualization, Methodology, Formal analysis, Investigation, Visualization, Supervision. C. JimenezLopez: Conceptualization, Methodology, Formal analysis, Investigation, Visualization, Supervision. M.A. Prieto: Conceptualization, Methodology, Formal analysis, Investigation, Visualization, Supervision. J. Simal-Gandara: Conceptualization, Methodology, Formal analysis, Investigation, Visualization, Supervision. 


\section{Declaration of Competing Interest}

The authors declare that they have no known competing financial interests or personal relationships that could have appeared to influence the work reported in this paper.

\section{Acknowledgements}

The research leading to these results was funded by FEDER under the European Union programme Interreg V Spain-Portugal (POCTEP, ref. 0377-Iberphenol-6-E; POCTEP, ref. 0181-Nanoeaters-01-E); by European Union Bio-Based Industries (Up4Health project) granted by H2020-BBI-JTI-2019; by MICINN supporting the Ramón\&Cajal grant for Miguel Ángel Prieto Lage (RYC-2017-22891); by the Xunta de Galicia and University of Vigo supporting the post-doctoral grant of María Fraga Corral (ED481B-2019/096), the pre-doctoral grants for Antia González Pereira (ED481A-2019/0228) and Paula García Oliveira (ED481A-2019/295); and by Axudas Conecta Peme (Xunta de Galicia) supporting the IN852A 2018/58 NeuroFood Project.

\section{References}

Aburjai, T., \& Natsheh, F. M. (2003). Plants Used in Cosmetics. Phytotherapy Research, 17(9), 987-1000. https://doi.org/10.1002/ptr.1363.

Ad'hiah, A. H., Al-Bederi, O. N. H., \& Al-Sammarrae, K. W. (2013). Cytotoxic effect of Agrimonia eupatoria L. against cancer cell lines in vitro. Journal of the Association of Arab Universities for Basic and Applied Sciences, 14(1), 87-92. https://doi.org/10. 1016/j.jaubas.2013.01.003.

Akram, M., Tahir, I. M., Shah, S. M. A., Mahmood, Z., Altaf, A., Ahmad, K., ... Mehboob, H. (2018). Antiviral potential of medicinal plants against HIV, HSV, influenza, hepatitis, and coxsackievirus: A systematic review. Phytotherapy Research, 32, 811-822. https://doi.org/10.1002/ptr.6024.

Al-snafi, A. E. (2015). The Pharmacological and therapeutic importante of Agrimonia eupatoria - A review. Asian Journal of Pharmaceutical Science \& Technology, 5(2), $112-117$.

Al-Snafi, A. E. (2019). Constituents and pharmacology of Geum urbanum-A review. Retrieved from www.iosrphr.org. IOSR Journal of Pharmacy, 9(5), 28-33.

Arslan, R., Bektas, N., Bor, Z., \& Sener, E. (2015). Evaluation of the antithrombotic effects of Crataegus monogyna and Crataegus davisii in the carrageenan-induced tail thrombosis model. Pharmaceutical Biology, 53(2), 275-279. https://doi.org/10.3109/ 13880209.2014.914957.

Asioli, D., Aschemann-Witzel, J., Caputo, V., Vecchio, R., Annunziata, A., Næs, T., \& Varela, P. (2017). Making sense of the "clean label" trends: A review of consumer food choice behavior and discussion of industry implications. Food Research International, 99, 58-71. https://doi.org/10.1016/J.FOODRES.2017.07.022.

Ayati, Z., Amiri, M. S., Ramezani, M., Delshad, E., Sahebkar, A., \& Emami, S. A. (2018). Phytochemistry, traditional uses and pharmacological profile of rose hip: A review. Current Pharmaceutical Design, 24(35), 4101-4124.

Bae, H., Kim, H.-J., Shin, M., Lee, H., Yin, C. S., Ra, J., \& Kim, J. (2010). Inhibitory effect of Agrimoniae Herba on lipopolysaccharide-induced nitric oxide and proinflammatory cytokine production in BV2 microglial cells. Neurological Research, 32(sup1), 53-57. https://doi.org/10.1179/016164109x12537002794002.

Barreira, J. C. M., Rodrigues, S., Carvalho, A. M., \& Ferreira, I. C. F. R. (2013). Development of hydrosoluble gels with Crataegus monogyna extracts for topical application: Evaluation of antioxidant activity of the final formulations. Industrial Crops and Products, 42(1), 175-180. https://doi.org/10.1016/j.indcrop.2012.05.034.

Barros, L., Carvalho, A. M., \& Ferreira, I. C. F. R. (2011). Comparing the composition and bioactivity of Crataegus monogyna flowers and fruits used in folk medicine. Phytochemical Analysis, 22(2), 181-188. https://doi.org/10.1002/pca.1267.

Benarba, B., \& Pandiella, A. (2018). Colorectal cancer and medicinal plants: Principle findings from recent studies. Biomedicine and Pharmacotherapy, 107, 408-423. https://doi.org/10.1016/j.biopha.2018.08.006.

Bespalov, V. G., Alexandrov, V. A., Semenov, A. L., Vysochina, G. I., Kostikova, V. A., \& Baranenko, D. A. (2018). The inhibitory effect of Filipendula ulmaria (L.) Maxim. on colorectal carcinogenesis induced in rats by methylnitrosourea. Journal of Ethnopharmacology, 227, 1-7. https://doi.org/10.1016/j.jep.2018.08.013.

Blanco, E., Macia, M. J., \& Morales, R. (1999). Medicinal and veterinary plants of El Caurel (Galicia, northwest Spain). Journal of Ethnopharmacolooy, 65, 113-124.

Borneo, R., León, A. E., Aguirre, A., Ribotta, P., \& Cantero, J. J. (2009). Antioxidant capacity of medicinal plants from the Province of Córdoba (Argentina) and their in vitro testing in a model food system. Food Chemistry, 112(3), 664-670. https://doi. org $/ 10.1016 /$ j.foodchem. 2008.06.027.

Cardoso, R. V. C., Fernandes, Â., Gonzaléz-Paramás, A. M., Barros, L., \& Ferreira, I. C. F. R. (2019). Flour fortification for nutritional and health improvement: A review. Food Research International, 125(May), 108576. https://doi.org/10.1016/j.foodres.2019. 108576.

Castroviejo, S. (1986). Flora iberica 1-8, 10-15, 17-18, 21. CSIC, Madrid: Real Jardín Botánico2012.

Corbo, M. R., Bevilacqua, A., Petruzzi, L., Casanova, F. P., \& Sinigaglia, M. (2014).
Functional Beverages: The Emerging Side of Functional Foods. Comprehensive Reviews in Food Science and Food Safety, 13(6), 1192-1206. https://doi.org/10.1111/15414337.12109.

Cosmulescu, S., Trandafir, I., \& Nour, V. (2017). Phenolic acids and flavonoids profiles of extracts from edible wild fruits and their antioxidant properties. International Journal of Food Properties, 20(12), 3124-3134. https://doi.org/10.1080/10942912.2016. 1274906.

Day, L. (2013). Proteins from land plants - Potential resources for human nutrition and food security. Trends in Food Science \& Technology, 32(1), 25-42. https://doi.org/10. 1016/J.TIFS. 2013.05.005.

de Santayana, M. P., Morales, R., Tardío, J., Aceituno, L., \& Molina, M. (2014). Inventario Epañol de los Conocimientos Tradicionales relativos a la Biodiversidad. https://doi.org/ 10.1017/СBO9781107415324.004.

de Santayana, M. P., Morales, R., Tardío, J., Aceituno, L., \& Molina, M. (2018). Inventario español de los conocimientos tradicionales relativos a la biodiversidad: Segunda fase (Tomo II): Fichas. Alimentación y Medio Ambiente: Ministerio de Agricultura.

Deliorman Orhan, D., Hartevioğlu, A., Küpeli, E., \& Yesilada, E. (2007). In vivo antiinflammatory and antinociceptive activity of the crude extract and fractions from Rosa canina L. fruits. Journal of Ethnopharmacology, 112(2), 394-400. https://doi.org/ 10.1016/j.jep.2007.03.029.

Dimitrova, L., Zaharieva, M. M., Popova, M., Kostadinova, N., Tsvetkova, I., Bankova, V., \& Najdenski, H. (2017). Antimicrobial and antioxidant potential of different solvent extracts of the medicinal plant Geum urbanum L. Chemistry Central Journal, 11(1), 1-11. https://doi.org/10.1186/s13065-017-0343-8.

El Haouari, M., \& Rosado, J. A. (2016). Medicinal Plants with Antiplatelet Activity. Phytotherapy Research, 1071, 1059-1071. https://doi.org/10.1002/ptr.5619.

EMA/HMPC/159076/2014. (2016). Assessment report on Crataegus spp., folium cum flore.

EMA/HMPC/434892/2010. (2013). Assessment report on Filipendula ulmaria (L.) Maxim., herba and Filipendula ulmaria (L.) Maxim., flos.

EMA/HMPC/680595/2013. (2015). Assessment report on Agrimonia eupatoria L., herba.

Escudero, F. A. M. (1999). Las plantas de extractos. Bases Para Un Plan de Desarrollo Del Sector [Medicinal and Aromatic Plants. Bases for a Development Plan of the Sector]. Mundi-Prensa, Madrid.

Febrer, J. L. F., Blanquer, G., \& Pí, A. S. (2001). Inventario de las plantas medicinales de uso popular en la ciudad de Valencia. Mediana y Ciencias Sociales, 13.

Fetni, S., Bertella, N., Ouahab, A., Martinez Zapater, J. M., \& De Pascual-Teresa Fernandez, S. (2017). Composition and biological activity of the Algerian plant Rosa canina L. by HPLC-UV-MS. Arabian Journal of Chemistry.. https://doi.org/10.1016/j. arabjc.2017.09.013.

Flood, J. (2010). The importance of plant health to food security. Food Security, 2(3), 215-231. https://doi.org/10.1007/s12571-010-0072-5.

Font Quer, P. (2001). Plantas medicinales. El Dioscórides renovado (Third edit) Barcelona (Spain).

Franco, R. R., Guitián, M. R., \& Resúa, Á. (2013). Plantas utilizadas en medicina humana y veterinaria en el municipio de Triacastela, Lugo (NW España). Recursos Rurais: Revista Oficial Do Instituto de Biodiversidade Agraria e Desenvolvemento Rura (IBADER), 35-43.

Fujii, T., Ikeda, K., \& Saito, M. (2011). Inhibitory effect of rose hip (Rosa canina L.) on melanogenesis in mouse melanoma cells and on pigmentation in brown guinea pigs. Bioscience, Biotechnology and Biochemistry, 75(3), 489-495. https://doi.org/10.1271/ bbb.100702.

Ganesan, P., \& Choi, D. K. (2016). Current application of phytocompound-based nanocosmeceuticals for beauty and skin therapy. International Journal of Nanomedicine, 11, 1987-2007. https://doi.org/10.2147/IJN.S104701.

Garmendia, F. M., \& Castroviejo, S. (1998). Crataegus L. Flora Iberica, 6, 404-414.

González-Hernández, M. P., Romero, R., Rodríguez-Guitián, M., \& Rigueiro, A. (2004). Medicinal use of some plants in Galicia (NW Spain). Acta Horticulturae, 629, 63-75.

Granica, S., Kłẹbowska, A., Kosiński, M., Piwowarski, J. P., Dudek, M. K., Kaźmierski, S., \& Kiss, A. K. (2016). Effects of Geum urbanum L. root extracts and its constituents on polymorphonuclear leucocytes functions. Significance in periodontal diseases. Journal of Ethnopharmacology, 188, 1-12. https://doi.org/10.1016/j.jep.2016.04. 030.

Gruenwald, J., Uebelhack, R., \& Moré, M. I. (2019). Rosa canina - Rose hip pharmacological ingredients and molecular mechanics counteracting osteoarthritis - A systematic review. Phytomedicine, 60, 152958. https://doi.org/10.1016/j.phymed.2019. 152958.

Guillén, A., \& Rico, E. (1998). Potentilla L. Flora Iberica, 6, 96-140.

Gulati, O. P., Ottaway, P. B., Jennings, S., Coppens, P., \& Gulati, N. (2019). Botanical nutraceuticals (food supplements and fortified and functional foods) and novel foods in the EU, with a main focus on legislative controls on safety aspects. In Nutraceutical and Functional Food Regulations in the United States and around the World (Third Edit, pp. 277-321). Doi: 10.1016/b978-0-12-816467-9.00020-4.

Hoffmann, J., Casetti, F., Bullerkotte, U., Haarhaus, B., Vagedes, J., Schempp, C. M., \& Wölfle, U. (2016). Anti-inflammatory effects of agrimoniin-enriched fractions of Potentilla erecta. Molecules, 21(6), https://doi.org/10.3390/molecules21060792.

Ivanova, D., Vankova, D., \& Nashar, M. (2013). Agrimonia eupatoria tea consumption in relation to markers of inflammation, oxidative status and lipid metabolism in healthy subjects. Archives of Physiology and Biochemistry, 119(1), 32-37. https://doi.org/10. 3109/13813455.2012.729844.

Jaberian, H., Piri, K., \& Nazari, J. (2013). Phytochemical composition and in vitro antimicrobial and antioxidant activities of some medicinal plants. Food Chemistry, 136(1), 237-244. https://doi.org/10.1016/j. foodchem.2012.07.084.

Jarzycka, A., Lewińska, A., Gancarz, R., \& Wilk, K. A. (2013). Assessment of extracts of Helichrysum arenarium, Crataegus monogyna, Sambucus nigra in photoprotective UVA and UVB; Photostability in cosmetic emulsions. Journal of Photochemistry and 
Photobiology B: Biology, 128, 50-57. https://doi.org/10.1016/j.jphotobiol.2013.07. 029.

Katanić, J., Boroja, T., Mihailović, V., Nikles, S., Pan, S. P., Rosić, G., ... Bauer, R. (2016). In vitro and in vivo assessment of meadowsweet (Filipendula ulmaria) as anti-inflammatory agent. Journal of Ethnopharmacology, 193, 627-636. https://doi.org/10 1016/j.jep.2016.10.015.

Katanić, J., Matić, S., Pferschy-Wenzig, E. M., Kretschmer, N., Boroja, T., Mihailović, V., ... Bauer, R. (2017). Filipendula ulmaria extracts attenuate cisplatin-induced liver and kidney oxidative stress in rats: In vivo investigation and LC-MS analysis. Food and Chemical Toxicology, 99, 86-102. https://doi.org/10.1016/j.fct.2016.11.018.

Laila, U., Akram, M., Shariati, M. A., Hashmi, A. M., Akhtar, N., Tahir, I. M., ... Ahmad, S. (2019). Role of medicinal plants in HIV/AIDS therapy. Clinical and Experimental Pharmacology and Physiology, (May), 1-11. Doi: 10.1111/1440-1681.13151.

Lee, K. Y., Hwang, L., Jeong, E. J., Kim, S. H., Kim, Y. C., \& Sung, S. H. (2010). Effect of Neuroprotective Flavonoids of Agrimonia eupatoria on Glutamate-Induced Oxidative Injury to HT22 Hippocampal Cells. Bioscience, Biotechnology and Biochemistry, 74(8), 1704-1706. https://doi.org/10.1271/bbb.100200.

Lennihan, B. (2014). The Practical Herbal Medicine Handbook. Berkeley (California) Althea Press.

Lima, M. J., Sousa, D., Lima, R. T., Carvalho, A. M., Ferreira, I. C. F. R., \& Vasconcelos, M. H. (2014). Flower extracts of Filipendula ulmaria (L.) Maxim inhibit the proliferation of the NCI-H460 tumour cell line. Industrial Crops and Products, 59, 149-153. https:// doi.org/10.1016/j.indcrop.2014.05.009.

Lobbens, E. S., Breydo, L., Skamris, T., Vestergaard, B., Jäger, A. K., Jorgensen, L., ... van de Weert, M. (2016). Mechanistic study of the inhibitory activity of Geum urbanum extract against $\alpha$-Synuclein fibrillation. Biochimica et Biophysica Acta - Proteins and Proteomics, 1864(9), 1160-1169. https://doi.org/10.1016/j.bbapap.2016.06.009.

López, C. J., Caleja, C., Prieto, M. A., Barreiro, M. F., Barros, L., \& Ferreira, I. C. F. R. (2018). Optimization and comparison of heat and ultrasound assisted extraction techniques to obtain anthocyanin compounds from Arbutus unedo L Fruits. Food Chemistry. https://doi.org/10.1016/j.foodchem.2018.04.103.

Lubbe, A., \& Verpoorte, R. (2011). Cultivation of medicinal and aromatic plants for specialty industrial materials. Industrial Crops and Products, 34(1), 785-801. https:// doi.org/10.1016/j.indcrop.2011.01.019.

Luís, Â., Domingues, F., \& Duarte, A. P. (2011). Bioactive Compounds, RP-HPLC Analysis of Phenolics, and Antioxidant Activity of Some Portuguese Shrub Species Extracts. Natural Product Communications, 6(12), 1934578X1100601219. Doi: 10.1177/ 1934578X1100601219.

Mantle, D., Eddeb, F., \& Pickering, A. T. (2000). Comparison of relative antioxidant activities of British medicinal plant species in vitro. Journal of Ethnopharmacology, 72(1-2), 47-51. https://doi.org/10.1016/S0378-8741(00)00199-9.

Mari, A., Eletto, D., Pizza, C., Montoro, P., \& Piacente, S. (2013). Integrated mass spectrometry approach to profile proanthocyanidins occurring in food supplements: Analysis of Potentilla erecta L. rhizomes. Food Chemistry, 141(4), 4171-4178. https:// doi.org/10.1016/j.foodchem.2013.06.101.

Mármol, I., Sánchez-de-Diego, C., Jiménez-Moreno, N., Ancín-Azpilicueta, C., \& Rodríguez-Yoldi, M. J. (2017). Therapeutic Applications of Rose Hips from Different Rosa Species. International Journal of Molecular Sciences, 18(6), https://doi.org/10. 3390/ijms18061137.

Martín Ortega, A. M., \& Segura Campos, M. R. (2019). Medicinal Plants and Their Bioactive Metabolites in Cancer Prevention and Treatment. In Bioactive Compounds (pp. 85-109). Doi: 10.1016/b978-0-12-814774-0.00005-0.

Martins, J., \& Brijesh, S. (2018). Phytochemistry and pharmacology of anti-depressant medicinal plants: A review. Biomedicine and Pharmacotherapy, 104(May), 343-365. https://doi.org/10.1016/j.biopha.2018.05.044.

Ministerio De Agricultura Alimentación y Medio Ambiente. (2019). Anthos. Sistema de información de las plantas de España.

Mosquera Paans, M. (2013). A nosa botica. Plantas medicinais (First; F. Villegas Belmonte, Ed.). Pontevedra: Edicións do Cumio.

Muruzović, M.Ž., Mladenović, K. G., Stefanović, O. D., Vasić, S. M., \& Čomić, L. R. (2016). Extracts of Agrimonia eupatoria as sources of biologically active compounds and evaluation of their antioxidant, antimicrobial, and antibiofilm activities. Journal of Food and Drug Analysis, 24, 539-547.

Nabavi, S. F., Habtemariam, S., Ahmed, T., Sureda, A., Daglia, M., Sobarzo-Sánchez, E., \& Nabavi, S. M. (2015). Polyphenolic composition of Crataegus monogyna Jacq.: From chemistry to medical applications. Nutrients, 7(9), 7708-7728. https://doi.org/10. 3390/nu7095361.

Nadpal, J. D., Lesjak, M. M., Šibul, F. S., Anačkov, G. T., Četojević-Simin, D. D., MimicaDukić, N. M., \& Beara, I. N. (2016). Comparative study of biological activities and phytochemical composition of two rose hips and their preserves: Rosa canina L. and Rosa arvensis Huds. Food Chemistry, 192, 907-914. https://doi.org/10.1016/j. foodchem.2015.07.089.

Neagu, E., Paun, G., Albu, C., \& Radu, G. L. (2015). Assessment of acetylcholinesterase and tyrosinase inhibitory and antioxidant activity of Alchemilla vulgaris and Filipendula ulmaria extracts. Journal of the Taiwan Institute of Chemical Engineers, 52 , 1-6. https://doi.org/10.1016/j.jtice.2015.01.026.

Ninomiya, K., Matsuda, H., Kubo, M., Morikawa, T., Nishida, N., \& Yoshikawa, M. (2007). Potent anti-obese principle from Rosa canina: Structural requirements and mode of action of trans-tiliroside. Bioorganic and Medicinal Chemistry Letters, 17(11), 3059-3064. https://doi.org/10.1016/j.bmcl.2007.03.051.

Nitta, Y., Kikuzaki, H., Azuma, T., Ye, Y., Sakaue, M., Higuchi, Y., ... Ueno, H. (2013). Inhibitory activity of Filipendula ulmaria constituents on recombinant human histidine decarboxylase. Food Chemistry, 138(2-3), 1551-1556. https://doi.org/10.1016/ j.foodchem.2012.10.074

Olennikov, D. N., Kashchenko, N. I., \& Chirikova, N. K. (2017). Meadowsweet teas as new functional beverages: Comparative analysis of nutrients, phytochemicals and biological effects of four Filipendula species. Molecules, 22(1), 1-23. https://doi.org/ $10.3390 /$ molecules 22010016 .

Ortega-Ramirez, L. A., Rodriguez-Garcia, I., Leyva, J. M., Cruz-Valenzuela, M. R., SilvaEspinoza, B. A., Gonzalez-Aguilar, G. A., ... Ayala-Zavala, J. F. (2014). Potential of medicinal plants as antimicrobial and antioxidant agents in food industry: A hypothesis. Journal of Food Science, 79(2), https://doi.org/10.1111/1750-3841.12341.

Ouerghemmi, S., Sebei, H., Siracusa, L., Ruberto, G., Saija, A., Cimino, F., \& Cristani, M. (2016). Comparative study of phenolic composition and antioxidant activity of leaf extracts from three wild Rosa species grown in different Tunisia regions: Rosa canina L., Rosa moschata Herrm. and Rosa sempervirens L. Industrial Crops and Products, 94, 167-177. https://doi.org/10.1016/j.indcrop.2016.08.019.

Owczarek, A., Gudej, J., \& Olszewska, M. A. (2015). Antioxidant activity of Geum rivale L. and Geum urbanum L. Acta Poloniae Pharmaceutica - Drug Research, 72(6), 1239-1244.

Owczarek, A., Olszewska, M. A., \& Gudej, J. (2014). Quantitative determination of ellagic acid and gallic acid in Geum rivale L And G. urbanum L. Acta. Biologica Cracoviensia Series Botanica, 56(2), 74-78. https://doi.org/10.2478/abcsb-2014-0021.

Oyenihi, A. B., \& Smith, C. (2019). Are polyphenol antioxidants at the root of medicinal plant anti-cancer success? Journal of Ethnopharmacology, 229(May), 54-72. https:// doi.org/10.1016/j.jep.2018.09.037.

Pahlow, M. (1994). El gran libro de las plantas medicinales (8th Editio; E. Everest, Ed.).

Pandey, A., \& Agnihotri, V. (2015). Antimicrobials from medicinal plants: Research initiatives, challenges, and the future prospects. In V. K. Gupta \& M. G. Tuohy (Eds.), Biotechnology of Bioactive Compounds: Sources and Applications (pp. 123-150). https://doi.org/10.1002/9781118733103.ch5.

Pawlaczyk-Graja, I. (2018). Polyphenolic-polysaccharide conjugates from flowers and fruits of single-seeded hawthorn (Crataegus monogyna Jacq.): Chemical profiles and mechanisms of anticoagulant activity. International Journal of Biological Macromolecules, 116, 869-879. https://doi.org/10.1016/j.ijbiomac.2018.05.101.

Pérez, I. C. (1998). El uso de las plantas medicinales. Medicina Clinica, 110(10), 399.

Pinela, J., Prieto, M. A., Carvalho, A. M., Barreiro, M. F., Oliveira, M. B. P. P., Barros, L., \& Ferreira, I. C. F. R. (2016). Microwave-assisted extraction of phenolic acids and flavonoids and production of antioxidant ingredients from tomato: A nutraceutical-oriented optimization study. Separation and Purification Technology, 164, 114-124. https://doi.org/10.1016/j.seppur.2016.03.030.

Reverter, M., Tapissier-Bontemps, N., Sasal, P., \& Saulnier, D. (2017). Use of Medicinal Plants in Aquaculture. In B. Austin \& A. Newaj-Fyzul (Eds.), Diagnosis and Control of Diseases of Fish and Shellfish (First edit, pp. 223-261). Doi: 10.1002/ 9781119152125.

Rivera, D., \& Obón, C. (1998). Guía de teoría y prácticas de Etnobotánica. Colección Textos Docentes. Murcia.

Rodrigues, S., Calhelha, R. C., Barreira, J. C. M., Dueñas, M., Carvalho, A. M., Abreu, R. M. V., ... Ferreira, I. C. F. R. (2012). Crataegus monogyna buds and fruits phenolic extracts: Growth inhibitory activity on human tumor cell lines and chemical characterization by HPLC-DAD-ESI/MS. Food Research International, 49(1), 516-523. https://doi.org/10.1016/j.foodres.2012.07.046.

Rodríguez González, A. (2008). Plantas medicinais de Galiza (A Nosa ter). Vigo.

Roleira, F. M. F., Tavares-Da-Silva, E. J., Varela, C. L., Costa, S. C., Silva, T., Garrido, J., \& Borges, F. (2015). Plant derived and dietary phenolic antioxidants: Anticancer properties. Food Chemistry, 183, 235-258. https://doi.org/10.1016/j.foodchem. 2015.03.039.

Romero, M. (2008). Catálogo da flora de Galicia. Monografías Do Ibader, (Instituto de Biodiversidade Agraria e Desenvolvemento Rural, Da USC), 1, 177.

Romero Martín, T. (1998). Agrimonia L. Flora Iberica, 6, 369-374.

Roriz, C. L., Barros, L., Prieto, M. A., Morales, P., \& Ferreira, I. C. F. R. (2017). Floral parts of Gomphrena globosa L. as a novel alternative source of betacyanins: Optimization of the extraction using response surface methodology. Food Chemistry, 229, 223-234.

Rosu, C. M., Manzu, C., Olteanu, Z., Oprica, L., Oprea, A., Ciornea, E., \& Zamfirache, M. M. (2011). Several fruit characteristics of Rosa sp. genotypes from the Northeastern region of Romania. Notulae Botanicae Horti Agrobotanici Cluj-Napoca, 39(2), 203-208.

Samaniego-Vaesken, M. L., Alonso-Aperte, E., \& Varela-Moreiras, G. (2016). Voluntary fortification with folic acid in Spain: An updated food composition database. Food Chemistry, 193, 148-153. https://doi.org/10.1016/j.foodchem.2014.06.046.

Samardžić, S., Arsenijević, J., Božić, D., Milenković, M., Tešević, V., \& Maksimović, Z. (2018). Antioxidant, anti-inflammatory and gastroprotective activity of Filipendula ulmaria (L.) Maxim. and Filipendula vulgaris Moench. Journal of Ethnopharmacology, 213, 132-137. https://doi.org/10.1016/j.jep.2017.11.013.

Sengupta, G., Gaurav, A., \& Tiwari, S. (2018). Substituting medicinal plants through drug synthesis. Synthesis of Medicinal Agents from Plants. https://doi.org/10.1016/b978-008-102071-5.00003-9.

Shalizar Jalali, A., \& Hasanzadeh, S. (2013). Crataegus monogyna fruit aqueous extract as a protective agent against doxorubicin-induced reproductive toxicity in male rats. Avicenna Journal of Phytomedicine, 3(2), 159-15970.

Shortle, E., Kerry, J., Furey, A., \& Gilroy, D. (2013). Optimisation of process variables for antioxidant components from Crataegus monogyna by supercritical fluid extraction (CO2) using Box-Behnken experimental design. Journal of Supercritical Fluids, 81, 112-118. https://doi.org/10.1016/j.supflu.2013.05.007.

Singh, B., Singh, S., Gulati, M., Singh, H., Arora, R., \& Arora, S. (2019). Herbal Products in Hypertension: Paradox or, Paragon. In Herbal Medicine: Back to the Future (pp. 76-124). Doi: 10.2174/9789811403743119020004.

Soutullo, E. C., Muñoz, C. F., Pazó, R. M., Alonso, R. M., \& Boente, M. J. R. (2015) Hierbas medicinales: uso en la cultura gallega. Revbigo.

Srivastava, A. K. (2018). Significance of medicinal plants in human life. In Synthesis of Medicinal Agents from Plants (pp. 1-24). Doi: 10.1016/B978-0-08-102071-5/ 00001-5

Stanković, M. S., Radić, Z. S., Blanco-Salas, J., Vázquez-Pardo, F. M., \& Ruiz-Téllez, T. (2017). Screening of selected species from Spanish flora as a source of bioactive 
substances. Industrial Crops and Products, 95, 493-501. https://doi.org/10.1016/j. indcrop.2016.09.070.

Synowiec, A., Gniewosz, M., Bączek, K., \& Przybył, J. L. (2014). Antimicrobial effect of an aqueous extract of Potentilla erecta rhizome. Herba Polonica, 60(2), 18-28. https:// doi.org/10.2478/hepo-2014-0007.

Tobyn, G., Denham, A., \& Whitelegg, M. (2011). Potentilla erecta, tormentil. Doi: 10. 1016/B978-0-443-10344-5.00029-X.

Tolve, R., Condelli, N., Caruso, M. C., Genovese, F., Di Renzo, G. C., Mauriello, G., \& Galgano, F. (2019). Preparation and characterization of microencapsulated phytosterols for the formulation of functional foods: Scale up from laboratory to semitechnical production. Food Research International, 116(2018), 1274-1281.

Tomczyk, M., \& Latté, K. P. (2009). Potentilla-A review of its phytochemical and pharmacological profile. Journal of Ethnopharmacology, 122(2), 184-204. https://doi.org/ 10.1016/j.jep.2008.12.022.

Tsirigotis-Maniecka, M., Pawlaczyk-Graja, I., Ziewiecki, R., Balicki, S., Matulová, M., Capek, P., ... Gancarz, R. (2019). The polyphenolic-polysaccharide complex of Agrimonia eupatoria L. as an indirect thrombin inhibitor- isolation and chemical characterization. International Journal of Biological Macromolecules, 125, 124-132.

Turan, I., Demir, S., Kilinc, K., Yaman, S. O., Misir, S., Kara, H., ... Deger, O. (2018). Cytotoxic effect of Rosa canina extract on human colon cancer cells through repression of telomerase expression. Journal of Pharmaceutical Analysis, 8(6), 394-399. https://doi.org/10.1016/j.jpha.2017.12.005.

Van Hai, N. (2015). The use of medicinal plants as immunostimulants in aquaculture: A review. Aquaculture, 446, 88-96. https://doi.org/10.1016/j.aquaculture.2015.03.

014

Verde, A. (2008). Guía de las plantas medicinales de Castilla-La Mancha

Verde, A., Rivera, D., Fajardo, J., Obón, C., \& Cebrián, F. (2008). Guía de las plantas medicinales de Castilla La Mancha (y otros recursos de uso tradicional) (E. Altabán, Ed.).

Vieira, V., Prieto, M. A., Barros, L., Coutinho, J. A. P., Ferreira, O., \& Ferreira, I. C. F. R. (2017). Optimization and comparison of maceration and microwave extraction systems for the production of phenolic compounds from Juglans regia L. for the valorization of walnut leaves. Industrial Crops and Products, 107, 341-352.

Wölfle, U., Hoffmann, J., Haarhaus, B., Rao Mittapalli, V., \& Schempp, C. M. (2017). Antiinflammatory and vasoconstrictive properties of Potentilla erecta - A traditional medicinal plant from the northern hemisphere. Journal of Ethnopharmacology, 204(April), 86-94. https://doi.org/10.1016/j.jep.2017.03.058.

Yoon, S. J., Koh, E. J., Kim, C. S., Zee, O. P., Kwak, J. H., Jeong, W. J., ... Lee, S. M. (2012) Agrimonia eupatoria protects against chronic ethanol-induced liver injuty in rats. Food and Chemical Toxicology, 50(7), 2335-2341. https://doi.org/10.1016/j.fct.2012.04. 005. 